\title{
1 A critical review of the use and performance of different function types for modeling
}

2 temperature-dependent development of arthropod larvae

$4 \quad$ Brady K. Quinn*

5 Department of Biological Sciences, University of New Brunswick, 100 Tucker Park Road, Saint

6 John, NB, Canada E2L 4L5

7 *Corresponding author: bk.quinn@unb.ca, 1-506-343-7676

9 Highlights: 6

- Temperature-dependent development functions of arthropod larvae were reviewed

- 79 published datasets were re-tested and fit with 33 different function types

- $91.1 \%$ of published studies did not fit their data with the best function of those tested

- Performance differed among functions and was related to taxon and temperature range tested

- Function type impacted predicted development times, so using the best function matters 


\section{ABSTRACT}

25 Temperature-dependent development influences production rates of arthropods, including crustaceans important to fisheries and agricultural pests. Numerous candidate equation types

27 (development functions) exist to describe the effect of temperature on development time, yet most studies use only a single type of equation and there is no consensus as to which, if any model predicts development rates better than the others, nor what the consequences of selecting a potentially incorrect model equation are on predicted development times. In this study, a literature search was performed of studies fitting development functions to development of

32 arthropod larvae (99 species). The published data of most (79) of these species were then fit with consequences of using a function other than the best one to model data were assessed. Performance was also related to taxonomy and the range of temperatures examined. The majority (91.1\%) of studies were found to not use the best function out of those tested. Using the incorrect model lead to significantly less accurate (e.g., mean difference \pm SE $85.9 \pm 27.4 \%$, range: -1.7 to $1725.5 \%$ ) predictions of development times than the best function. Overall, more complex functions performed poorly relative to simpler ones. However, performance of some complex functions improved when wide temperature ranges were tested, which tended to be

42 the biological significance of choosing the best-fitting model to describe temperature-dependent 43 development time data. 


\section{Introduction:}

Temperature affects biota at all levels, ranging from effects at the fundamental biochemical and physiological levels (Bělehrádek, 1935; Coutant and Talmage 1976; Somero, 2004) to effects on individual organisms (Brière et al., 1999; MacKenzie, 1988), populations (Aiken and Waddy, 1986; Cooper et al., 2012; McLaren et al., 1969), communities, and ecosystems (Menge, 1978; McQuaid and Branch, 1985). Through its effects on the physical and chemical properties of biologically active molecules, such as enzymes, temperature affects the rate at which numerous life processes occur, including metabolism, oxygen consumption, photosynthesis, movement, survival, growth, and embryonic development (Bělehrádek, 1935; Brière et al. 1999; Corkett, 1972; Coutant and Talmage 1976; Du et al., 2007; Geffen and Nash, 2012; Herzig, 1983; McLaren et al., 1969). Temperature also significantly affects larval development rate of poikilothermic animals, including some vertebrate larvae (Lind and Johansson, 2007; Kang et al., 2009; Miller et al., 2006) and those of invertebrates (e.g., de Severyn et al., 2000; Jenkins et al. 2006; Singh and Sharma, 1994). Temperature has particularly strong impacts on moulting and development of arthropods (Anger, 1984; Corkett and McLaren, 1970; Easterbrook et al., 2003; Hamasaki et al., 2009; Koda and Nakamura, 2010; MacKenzie, 1988; Marchioro and Forester, 2011; McLaren, 1963).

Within certain tolerance limits (Bělehrádek, 1935; Brière et al., 1999; Campbell et al., 1974; Shi and Ge, 2010) rates of biological processes of poikilotherms, including larval development, are positively correlated with temperature; thus, higher temperatures generally result in more rapid development than lower temperatures. This has important ecological implications, as environmental temperatures can influence generation times, production cycles, and population dynamics of such organisms. Higher or lower temperatures could, for example, 
lead to changes in the amount and/or timing of peak secondary marine production of copepods

71 (Huntley and López, 1992; McLaren, 1963), outbreaks of agricultural pests (Easterbrook et al.,

72 2003) or vector-borne diseases (Bayoh and Lindsay, 2003), or introduction and establishment of

73 invasive species into new areas (de Rivera et al., 2007). Water temperatures could also influence

74 patterns of recruitment to populations of marine invertebrates, including crustaceans such as

75 lobsters and crabs, on which human fisheries depend (Aiken and Waddy, 1986; Anger, 1984;

76 Caddy, 1986; MacKenzie, 1988; Rothlisberg, 1979). represent the functional relationship between environmental temperature and development rate or time of larvae. These equations, hereafter referred to as development functions, are derived by rearing larvae at different controlled temperatures in a lab or hatchery setting, observing development times of multiple larvae at each temperature, and then using regression analyses to

82 fit an equation relating temperature to development time (or its inverse, rate) to the data obtained.

83 There are countless potential forms of equation that can be used to fit such data, including various linear, simple curvilinear, and complex non-linear functions (e.g., see reviews by Anger, 2001; Angilleta Jr., 2006; Blanco et al. 1995; Guerrero et al., 1994; Heip, 1974; Kontodimas et al., 2004; McLaren, 1995; Shi and Ge, 2010; Smits et al. 2003). These functions differ in form, assumptions, procedures used to derive their parameters, and most importantly in terms of the development times predicted. For example, development times of American lobster, Homarus americanus (H. Milne Edwards, 1837), larvae predicted with 33 of these development function types can differ from each other and the data used to derive them by $\geq 50$ days at the same

91 temperatures (see Fig. 1; Table S1). However, this is no clear standard rule or consensus as to

92 what is the "best" type of development function to apply to these kinds of data. Researchers are 
93 generally left to choose the type of development function to use on their own, and will often

94 select one or a very few forms that have the best apparent match to their characters of their data

95 or has been used by other studies on the same or related species (e.g., Edgar and Andrew, 1990;

96 McLaren et al., 1969). Given the potential for different functions to make very different

97 predictions of development times (e.g., Fig. 1), however, development function choice should be

98 given more consideration in studies on these species.

It is possible that certain function types may in general be better representations of the

100

101

102

103

104

105

106

107

108

109

110

111

112

113

114

115

relationship between temperature and development of arthropod larvae, or specific sub-groups

within the Arthropoda (e.g., arachnids vs. crustaceans vs. insects), for example because they

come closer to capturing thermal performance relations of enzymes and other biomolecules

mediating moulting and development cycles in these taxa (Brière et al., 1999; Huey and

Stevenson, 1979; Somero, 2004). As a result, such functions might also achieve better fit to

development data, be able to more-closely match real observed development times, and make

better predictions of development in nature. Differences in methodologies used in studies on

different taxa, for example the fact that the range of temperatures tested is generally wider for

insects and arachnids than crustaceans; (reviewed by Hartnoll, 1982; Quinn and Rochette, 2015),

might also lead to apparent taxonomic differences in function performance and should be

investigated. Several previous studies have compared the characteristics of different

development function types in general (Anger, 2001; Blanco et al., 1995; Guerrero et al., 1994;

McLaren, 1995). Others have examined performance of one or two specific functions on

multiple species (e.g., Logan et al., 1976), or attempted to fit multiple function types to data for

one or two specific species under study to select the best function for their data (e.g., Angilletta

Jr., 2006; Heip, 1974; Kontodimas et al., 2004; Shi and Ge, 2010; Smits et al., 2003). Many other 
116

117

118

119

120

121

122

123 124 larval development.

125

126

127

128

129

130

131

132

133

134

135

136

137

138

studies seem to choose one or very few function(s) semi-arbitrarily, without discussing

alternatives (e.g., de Oliveria et al., 2009; Thompson 1982; see also Results). However, no

previous study has attempted to assess the degree to which one versus multiple types of

development functions are used in published studies, compared performance of different types of development functions across multiple species, or assessed the overall impact of function choice

to predictions made with such functions. Such a large-scale analysis is needed, though, because it could potentially allow functions that tend to better represent development data in general to be

identified, which can then allow for more informed decisions by future studies on arthropod

In this study, a critical literature review was conducted to assess whether and to what extent studies of temperature-dependent development of arthropod larvae attempt to represent their data with more than one development function type, and also which specific types of functions tend to be used. Then, data from previously published studies were extracted and retested to derive multiple different development functions for the same datasets. The best model type for each dataset was determined, and whether or not published studies actually used the best function type for their data was recorded. Overall performance of different function types were assessed by comparing overall function rankings, proportion of variance explained, and information loss across datasets. Any taxonomic patterns (e.g., whether particular function types performed better for arachnids than for crustaceans and/or insects) and whether performance was related to the range of temperatures tested were also noted. The consequences of using different function types were then tested by comparing the difference of predicted versus observed development times, fit, and information loss of the function type used in original studies versus that of the best function for the data. 


\section{Materials and methods:}

\subsection{Literature review:}

A literature search was conducted through Web of Science (Thompson Reuters, 2015) for the terms "temperature" AND "development". An initial search was carried out on 12 September 2012, through which the majority of the data in the present study were obtained; this search

146 yielded 1,052 results. A second search was carried out on 19 November 2014, which returned 35 147 additional results not available or published online at the time of the initial search. These 1,087 total search results were them further examined, and several criteria were used to remove non-

149 relevant results. Accessible peer-reviewed studies that reported larval development rates or times 150 of arthropods at different temperatures and derived a regression equation(s) (i.e., development

151 function) from their data were sought out. Studies that looked exclusively at growth (size increase), which is a distinct process from development (Forster et al., 2011), were excluded. After applying these criteria, 81 studies of 96 different arthropod species were obtained,

154 which provided a total of 99 species datasets for subsequent examination and analyses (Table S2).

155 Several specific types of development function were frequently utilized in these studies (Table

156 S2); these functions are presented in Table 1 and discussed in the next section (2.2.1, below).

157 Studies were published between 1970 and 2014, and conducted in several different countries on

158 marine, freshwater, and terrestrial species (Table S2) of various taxa within the Arachnida 159 (Phylum Arthropoda: Subphylum Chelicerata), Crustacea, and Insecta (Table S2). To assess whether published studies tested multiple development functions on their data, each study was carefully read and the number and types of development functions used to fit the data for each 
162

163

164

165

166

167

168

169

170

171

172

173

174

175

176

177

178

179

180

181

182

183

184

study species were noted. Even if results from multiple functions were not reported, if alternative functions than reported were at least mentioned in the Methods sections of studies they were counted as having considered $>1$ function. Also if any study tested multiple development functions on their data and concluded one of these to be the "best" function for their data this was also noted. The percent (\%) of the 99 species datasets from the literature search on which one, two, or more functions were tested, and the $\%$ of datasets on which different types of functions were tested, were then calculated.

2.2. Meta-analysis:

\subsubsection{Development functions considered in this study:}

In the present study, 33 development function types were examined (Table 1; Figure 1).

These functions were used because they were found in the literature review in the present study

(see section 2.1 and Results) to be used quite frequently in studies of arthropod larvae, and were discussed in reviews and studies on the topic of arthropod temperature-development functions by Anger (2001), Guerrero et al. (1994), Heip (1974), Kontodimas et al. (2004), and Shi and Ge (2010). Three linear and 30 nonlinear functions were examined, with $k$-values $(k=$ numbers of parameters + 1; Anderson, 2008) ranging from 3 to 8 (Table 1). Eight of these functions are fit directly to development time data, while the remaining 25 functions are typically fitted to development rate data, which are the inverse of time (Table 1); in some cases, the same function form (e.g., quadratic) is applied to either development rate (function \#15, Table 1) or time (\#16), yielding distinct functions (Fig. 1). 12 of these functions included a nonzero minimum temperature $\left(\mathrm{T}_{\min }\right)$ for development at which development rate is zero and development time becomes infinite (see Fig. 1), 15 included a similar maximum temperature for development 
$185\left(\mathrm{~T}_{\max }\right)$, and 8 functions included both of these thresholds (Table 1). Linear functions can be used

186 to derive starting estimates for the values of $\mathrm{T}_{\min }$ and $\mathrm{T}_{\max }$ (Campbell et al., 1974; Kontodimas et

187 al., 2004; Table 1) to be used in deriving more complicated nonlinear functions. Attempts were

188 also made to test three additional functions found in these reviews: the Exponentially Modified

189 Gaussian (Naish and Hartwell, 1988), Sharpe-Schoolfield-Ikemoto (SSI; Sharpe and DeMichele,

190 1977; Schoolfield et al., 1981), and Weibull (Angilletta Jr., 2006) functions. However, these

191 three functions have very complex structures requiring specialized fitting procedures not readily

192 applicable in many statistical software packages (see review by Shi and Ge, 2010), and in the

193 present study they could not be fit to the datasets used; as such, they were not considered further

194 in this study.

195

196

\subsubsection{Re-analysis of species datasets from published studies:}

To assess whether the function(s) used in published studies were actually the "best"

199 functions for these published datasets, data were extracted for re-analysis from as many of the

200 studies obtained through the literature search described above as possible. Studies from the

201 literature search that did not present their data in a way that allowed it to be extracted for

202 retesting (e.g., only mean development times resented, without any measure of error), had to be

203 excluded. Therefore, only 79 species datasets out of the 99 initially obtained from the literature

204 search could be retested (Table S2); these included 10 arachnids (9 mites in the Subclass Acari

205 and one spider in Subclass Aranea), 28 Crustaceans (9 copepods and 19 decapods), and 41

206 insects in 8 orders (8 Coleoptera, 6 Diptera, 9 Hemiptera, 1 Homoptera, 1 Heteroptera, 8

207 Hymenoptera, 6 Lepidoptera, and 2 Thysanoptera) (Table S2). Raw data or means \pm error 
208 (standard deviation (SD), standard error (SEM), etc.) and sample sizes were extracted from

209 tables or figures in published papers for each of these 79 species and used to generate datasets

210 for reanalysis.

211 Each study dataset was analyzed with linear and nonlinear regressions (Table 1) between

212 temperature and development time or rate, as appropriate. These regression were carried out

213 using IBM SPSS Statistics 22 (SPSS Inc., 2014). To simplify analyses, only total development

214 times or rates (i.e., summed across multiple larval stages) were examined and data for individual

215 stages were not. For development functions including thermal limits or other parameters with

216 biological meaning (e.g., $\mathrm{T}_{\min }$ or $\mathrm{T}_{\max }$; see Table 1 and section 2.2.1), unconstrained regressions

217 were initially carried out, with starting values for these parameters set to values estimated from

218 linear functions (see Table 1 and section 2.2.1, above). However, results were not accepted if this

219 yielded biologically unrealistic estimates, such as $\mathrm{T}_{\min }<0^{\circ} \mathrm{C}$ in a species not known to survive

220 and develop at sub-zero temperatures, unreasonably low $\mathrm{T}_{\min }\left(\right.$ e.g., $-100^{\circ} \mathrm{C}$ ) or high $\mathrm{T}_{\max }$ (e.g.,

$221100^{\circ} \mathrm{C}$ ), or $\mathrm{T}_{\min }$ or $\mathrm{T}_{\max }$ within the temperature range for which successful development was

222 reported in the original study. In this case, constrained regressions were carried out (e.g., $\mathrm{T}_{\min } \geq$

$2230^{\circ} \mathrm{C}, \mathrm{T}_{\min }<\operatorname{minimum} \mathrm{T}$ with successful development, $\mathrm{T}_{\max }>$ maximum $\mathrm{T}$ with successful

224 development, etc.) until satisfactory values were obtained.

225 Once a regression equation corresponding to each development function was obtained for

226 each dataset, $\mathrm{AIC}_{\mathrm{C}}$ values (Akaike's Information Criterion (AIC) corrected for finite sample size;

227 Akaike, 1973; Anderson, 2008) were calculated using the residual sum of squares (RSS) between

228 observed development times and those predicted by each function for each study (Anderson,

229 2008). Development functions were then ranked for each species dataset based on $\mathrm{AIC}_{\mathrm{C}}$-values.

230 The "best" possible rank was 1, corresponding to the lowest $\mathrm{AIC}_{\mathrm{C}}$ value, and the "worst" 
231 possible rank - if there were no ties - was 33, which corresponded to the highest AIC $\mathrm{C}_{\mathrm{C}}$ value

232 among the functions tested. The percentage of retested datasets for which each of the 33

233 functions was concluded to be "best" was recorded. For each species dataset, whether or not the

234 function used in its original published study and concluded to be the "best" function for the data

235 was the same as that determined to be the "best" function in this study was noted. If more than

236 one function was used in an original study, whether the actual best function was among all these

237 functions was also noted. RSS values were also used to calculate $\mathrm{R}^{2}$-values for each function, on

238 each dataset. These values were used as a measure of function performance (see next section,

239 2.2.3), indicating the proportion of the variation in observed development times that was

240 explained by each temperature-dependent development function.

To determine whether any particular type(s) of function tended to do "better" than others,

244 the overall performance of each development function across species datasets was assessed using

245 three measures: average ranking (determined using $\mathrm{AIC}_{\mathrm{C}}$ ), $\mathrm{R}^{2}$, and $\Delta_{\mathrm{i}}$ values. These measures of

246 performance were also compared across different taxonomic groups (arachnids, crustaceans, and

247 insects) as it was possible that certain functions might better represent development of animals in

248 a certain group(s) better than animals in others; this could be due to real biological differences

249 among taxa or to different experimental methodologies used for their rearing.

251 described above (previous section). $\Delta_{\mathrm{i}}$ values were calculated once the best function for a given

252 dataset was determined to assess the information potentially lost by using a function other than

253 the best one (Anderson, 2008); a lower $\Delta_{\mathrm{i}}$ value is better, and indicates less information loss. The 
$254 \Delta_{\mathrm{i}}$ value for a given function, "i", is calculated by subtracting the $\mathrm{AIC}_{\mathrm{C}}$ value of the best function 255 of those tested from its $\mathrm{AIC}_{\mathrm{C}}$ value (Anderson 2008); therefore, the best function will have $\Delta_{\mathrm{i}}=$

2560 . A function with a lower $\Delta_{\mathrm{i}}$, higher $\mathrm{R}^{2}$, or lower (better) ranking value on average than other

257 functions was considered to have performed better overall than other functions. 2014) to compare each of these three measures of performance (rankings, $\mathrm{R}^{2}$, and $\Delta_{\mathrm{i}}$ ) across different development functions (factor with 33 levels; Table 1), as well as among different taxonomic groups (factor with 3 levels: Arachnida, Crustacea, and Insecta). $\mathrm{R}^{2}$-values were arcsine-square root transformed to meet the assumptions of parametric tests. If a statisticallysignificant $(\mathrm{p} \leq 0.05)$ interaction between function and taxon was found, the data for that measure were split by taxon and then separate one-way ANOVAs comparing different functions were carried out for each taxon. If significant differences among functions were found, Tukey's Honestly Significant Difference (HSD) test was used to perform post-hoc comparisons among specific function types.

\subsubsection{Assessing the consequences of development function choice:}

271 at different temperatures were assessed by comparing whether and how much the best or only

272 function originally used in the study from which each species dataset was obtained ("original

273 best" function) predicted observed development times relative to the best function identified in

274 this study ("actual best" function). Three measures, described in detail below, were calculated for

275 each of the 79 species datasets to assess consequences of function choice. These were mean error,

$276 \mathrm{R}^{2}$ decrease, and $\Delta_{\mathrm{i}}$ resulting from using the original study function instead of the actual best one. 
To calculate the first of these, error, the absolute deviance (in days) between predicted

278 (using a development function) and observed development time was calculated for both the best

279 and original study functions, at each temperature tested in original studies. The absolute deviance

280 for the actual best function was then subtracted from that for the original best/used function at

281 each temperature, to determine how much predictions were worse (i.e., further from observed

282 values) when using the original versus best function. These differences were then averaged

283 across all temperatures and data points to calculate a mean absolute error (in days) per each

284 dataset that was due to using the original versus actual best functions. Mean error per dataset was

285 also expressed as a percent improvement by performing the aforementioned calculations, but

286 before averaging differences between deviance of original and actual best functions across

287 temperatures these differences were divided by the best function's deviance and multiplied by

$288100 \%$; this translated the error from a "raw" measure (in days) to a percentage (\%).

$\mathrm{R}^{2}$ decrease was simply calculated for each dataset by subtracting the $\mathrm{R}^{2}$-value of that

dataset's actual best function from that of its original used function. Percent $\mathrm{R}^{2}$ increase was also

291 calculated for each dataset by dividing the $\mathrm{R}^{2}$ change by the best function's $\mathrm{R}^{2}$, and then

292 multiplying by $100 \%$. A large $\mathrm{R}^{2}$ decrease implied that a lower proportion of the variation in

293 development time was explained by the original function than the best one.

The $\Delta_{\mathrm{i}}$ of the original function for each dataset was also examined to assess the extent of

295 potential information lost by using these, rather than the best functions, to fit the data. As

296 described above, a lower $\Delta_{\mathrm{i}}$ (closer to $0=\Delta_{\mathrm{i}}$ of best function) is better, and implies the function

297 retains more useful information than a function with a higher $\Delta_{\mathrm{i}}$. Generally a function with $\Delta_{\mathrm{i}}<2$

298 contains some useful information, even if it is not the "best" function, whereas a function with $\Delta_{\mathrm{i}}$ 
$>14$ is highly unlikely to be informative (Anderson 2008). A high original function $\Delta_{\mathrm{i}}$ value would imply that the original function was considerably less informative than the best function.

If the best function for a given dataset was the same as the original function, all of the measures described above would have a value of zero; if any measure were not significantly different from zero, then, it would imply that using the best versus original function did not result in meaningfully different predicted development times. Therefore, the distributions of each measure of the consequences of using a function other than the best one (mean errors and $\mathrm{R}^{2}$ decrease (both raw and \% versions), as well as original function $\Delta_{\mathrm{i}}$ values) across all species datasets were compared to zero (null hypothesis of no differences) using five one-sample $t$-tests. If the null hypothesis comparing these data against zero-values could be rejected, then a significant $(\mathrm{p}<0.05)$ impact of function choice was concluded.

\subsection{Potential relationship between thermal range and function performance:}

One interesting pattern noted during the literature review in this study was that studies of temperature-dependent development differed considerably in their methodology, particularly regarding the range of temperatures tested. Thermal ranges varied considerably among studies in general, from as narrow as $6^{\circ} \mathrm{C}$ to as wide as $38^{\circ} \mathrm{C}$ (Table S2). Differences also appeared to exist between studies of different taxonomic groups, particularly between studies of crustaceans versus those of arachnids and insects (Hartnoll, 1982; Quinn and Rochette, 2015; Table S2). To confirm whether such taxonomic differences were significant, the thermal range for each species dataset obtained in the initial literature search $(n=99$ total $)$ was calculated as the maximum temperature tested in its original study minus the minimum temperature tested; this included any temperatures at which successful development was not observed (i.e., survival $=0 \%$ ), as this 
322 implies a developmental threshold (i.e., $\mathrm{T}_{\min }$ and $\mathrm{T}_{\max }$; see Table 1). One-way ANOVA was then

323 used to compare thermal ranges among the three major taxonomic groups of arthropods.

325 datasets (Angilletta Jr., 2006; Shi and Ge, 2010). This is especially true for functions containing

326 threshold temperatures $\left(\mathrm{T}_{\min }\right.$ and $\left.\mathrm{T}_{\max }\right)$ if these are fit to data recorded over narrow thermal

327 ranges not approaching a species' real thermal limits (Shi and Ge, 2010). In such cases, thermal

328 thresholds have to be extrapolated too far beyond actual observations, resulting in excessively

329 extreme estimates for these parameters. One could thus expect that more complex functions may

330 perform better when wider thermal ranges are tested, potentially approaching or encompassing

331 real thermal limits. To test whether or not more complex functions would be selected as better

332 functions when wider thermal ranges were tested, Pearson's correlation coefficients (R) were

333 calculated between the thermal ranges calculated for each dataset and the ranking of each

334 function per dataset. Thus, 33 separate correlation analyses were carried out (one for each type of

335 development function), each consisting of 99 thermal range-ranking pairs (one pair per dataset).

336 Whether correlations were significant $(\mathrm{p} \leq 0.05)$, and if significant $\mathrm{R}$-coefficients were positive

337 or negative was examined. As lower ranking values implied better function performance (see

338 above), a positive correlation for a given function implied that the function did worse when a

339 wider range of temperatures was tested, whereas a negative correlation meant that the function

340 did better when a wider thermal range was tested.

\section{Results:}

$344 \quad 3.1$. Results of literature review - usage of different functions: 
Out of 99 different species datasets, over half $(59.6 \%)$ were reported to have been fit with only one development function and the vast majority $(96.0 \%)$ were fit with five or fewer functions (Fig. 2). In most cases studies that used 2-5 functions examined insects or arachnids (Fig. 2) and used 1-3 more complex functions plus the linear rate (function \#5) or Ikemoto and Takai (\#4) functions to derive starting values for $\mathrm{T}_{\min }$ and $\mathrm{T}_{\max }$ parameters in these complex functions (Table S2; see also below and Fig. 3). The only taxonomic group for which > 5 different functions were tested was Insecta, for which $4.0 \%$ of all species datasets (representing $7.8 \%$ of insects) were tested with 5-17 different development functions (Fig. 2). datasets and representing 28.4 and $15.2 \%$ of insect and arachnid datasets, respectively (Fig. 3A; further functions types were used (Fig. 3A). Functions used on insects and arachnids ranged in complexity from relatively simple $(k=3)$ to very complex $(\# 33, k=8)$, but with no particular function aside from the linear rate one (\#5) predominating (Fig. 3A). Studies of Crustacea used a more limited set of 8 functions, all but one of which (function $\# 16, k=4$ ) were relatively simple (\#1-3 and 5-8, $k=3$ ) (Fig. 3A). The Heip power function (\#2) was the most commonly-used

362 function for Crustacea ( $9.4 \%$ of all datasets, or $35.1 \%$ of crustaceans), followed by the Bělehrádek (\#8, $6.6 \%$ of datasets or $24.6 \%$ of crustaceans) and Tauti or exponential (\#7, $4.7 \%$

364 of datasets, $17.5 \%$ of crustaceans) functions (Fig. 3A). The distribution of best functions as

365 concluded in reviewed studies showed a similar pattern, with the linear rate function (\#5)

366 dominating for insects and arachnids and the Heip power function (\#2) most often being

367 concluded best for crustacean data (Fig. 3B). Among insects and arachnids, the Brière-1 function 
368 (\#9) showed a slight tendency to be selected as best more often than other nonlinear functions, as

369 it was for $7.0 \%$ of all datasets, representing $6.7 \%$ of insects and $18.2 \%$ of arachnids (Fig. 3B).

373 the "best" function for these data in their original studies were found, in the vast majority of

374 cases, not to be the best function for the data out of the 33 functions examined (Fig. 4). When

$375 \mathrm{AIC}_{\mathrm{C}}$ was used to rank functions, the best function for $91.1 \%$ of 79 retested study datasets was

376 concluded to be a different one than that selected in previous studies (Fig. 4A), and for $86.1 \%$ of

377 datasets the actual best function was not even included in the set of all functions used in original

378 studies (Fig. 4B). The actual best function was found to be different from that concluded to be

379 best in original studies for all (100\%) arachnid and insect studies examined, and for most

$380(75.0 \%)$ crustacean studies (Fig. 4A). Also, for all taxonomic groups a considerable majority of

datasets (100\% of Arachnida, $67.9 \%$ of Crustacea, and $95.1 \%$ of Insecta) were found to be best

fit using a function that was not used in original studies of these species (Fig. 4B).

No one function was found to always be the "best" or "worst" for all reanalyzed datasets, best function by $\mathrm{AIC}_{\mathrm{C}}$ particularly often (i.e., for $\geq 10 \%$ of datasets) were the Heip power (\#2), 
400

401

402

403

404

405

406

407

408

409

410

411

412

413

complex functions with $k>5$ were rarely concluded to be best (Fig. 5). Of the 33 functions tested, 16 were also never concluded to be the best of those tested (Fig. 5).

There were significant interactions between the effects of taxonomic group and development function type on overall performance of the 33 different development functions as assessed with $\mathrm{R}^{2}$-values $\left(\mathrm{F}_{64,2508}=1.377, \mathrm{p}=0.026\right)$ and by ranking functions with $\mathrm{AIC}_{\mathrm{C}}\left(\mathrm{F}_{64}\right.$, $2508=2.362, \mathrm{p}<0.001)$. Therefore differences in $\mathrm{R}^{2}$ and rank among functions were compared for each taxonomic group separately. In all three taxonomic groups, $\mathrm{R}^{2}$-values (Arachnida: $\mathrm{F}_{32}$, $297=1.783, \mathrm{p}=0.007 ;$ Crustacea: $\mathrm{F}_{32,891}=3.721, \mathrm{p}<0.001 ;$ Insecta: $\left.\mathrm{F}_{32,1320}=2.868, \mathrm{p}<0.001\right)$ and ranks significantly differed among different development functions (Arachnida: $\mathrm{F}_{32,297}=$ 5.724, $\mathrm{p}<0.001$; Crustacea: $\mathrm{F}_{32,891}=14.707, \mathrm{p}<0.001$; Insecta: $\left.\mathrm{F}_{32,1320}=17.823, \mathrm{p}<0.001\right)$. However, overall $\Delta_{\mathrm{i}}$ values were found to not differ significantly among functions $\left(\mathrm{F}_{32,2508}=\right.$ $0.278, \mathrm{p}>0.999)$ or taxonomic groups $\left(\mathrm{F}_{2,2508}=1.0, \mathrm{p}=0.368\right)$, nor was there a significant interaction between the effects of these factors on $\Delta_{i}$ values $\left(F_{64,2508}=0.448, p>0.999\right)$.

Differences in fit $\left(\mathrm{R}^{2}\right)$ and rankings among functions were actually very similar across the different taxonomic groups (Fig. 6A-F; Table 2). Most function had relatively high overall average $\mathrm{R}^{2}$-values between 0.7 and 0.9 or higher (Fig. 6A-C), so on average, all temperaturedependent development functions tested were able to explain the majority of variation in observed development times. Functions with notably lower fit compared to others (lowest mean = 0.476) did occur, though, and included the linear time (\#6) Logan-6 (function \#25), Logan-10 (\#30), and W-L-D (\#33) functions on arachnid and insect data (Fig. 6A, C; Table 2), and the Ratkowsky (\#27), Brière-1 (\#9) and Brière-2 (\#20) functions on crustacean data (Fig. 6B; Table 2). The explanatory power of development functions therefore differed by as much as ca. 10$50 \%$ on average depending on which was used (Fig. 6A-C). Functions with lower (better) overall 
414 ranks for all taxonomic groups included the Heip (\#2), Hyperbola (\#3), Bĕlehrádek (\#8),

415 quadratic time (\#16), and $3^{\text {rd }}$ order polynomial time (\#19) functions (Fig. 6D-E; Table 2), and

416 those with high (poor) overall ranks included those with low $\mathrm{R}^{2}$-values described above and the

417 Holling Type III (\#21) functions (Fig. 6D-E; Table 2). All mean $\Delta_{\mathrm{i}}$ values were high (mean $\Delta_{\mathrm{i}} \geq$

418 22.7) because each function was not selected as the best function by $\mathrm{AIC}_{\mathrm{C}}$ at least once, and in

419 many cases the difference between the $\mathrm{AIC}_{\mathrm{C}}$ values of the best function and the $2^{\text {nd }}$ best function

$420\left(\Delta_{\mathrm{i}}\right)$ were quite large (as evidenced by the variance in Fig. 6G-I). There were therefore large

421 differences in the amount of information attained depending on which function was used, but no

422 clear pattern among functions or taxa (Fig. 6G-I).

\subsection{Consequences of function choice:}

All measures of prediction error, decreased fit, and increased information loss resulting

426 from using the best original rather than the actual best functions on species datasets were

427 significantly different from zero (one-sample $t$-tests, $\mathrm{p}<0.05$; Table 2). Development times

428 predicted with original studies' functions disagreed with observed developmental duration by

429 about 4 days or $85.9 \%$ on-average, but could be off by as much as 132 days or $1725.5 \%$ (Table

430 3). Fit $\left(\mathrm{R}^{2}\right)$ of original functions to arthropod datasets was lower by 0.091 on-average compared

431 with best functions (Table 3), meaning that nearly $10 \%$ of the variation in the data would remain

432 unexplained if the original rather than the actual best function was used. The difference in $\mathrm{R}^{2}$ -

433 values between originally-used and best functions could be much greater in many cases, though,

434 as percent decrease in $\mathrm{R}^{2}$ by using the best function was as high as $100 \%$ for certain study

435 datasets (Table 3; Table S2). Additionally the mean $\Delta_{\mathrm{i}}$ of the originally-used functions was 225 
436 and could be as high as 3958.7 for some datasets (Table 3), indicating a substantial loss of

437 information relative to the actual best function as determined in the present study.

3.5. Range of temperature tested in studies versus function performance:

441 taxonomic groups $\left(\mathrm{F}_{2,96}=16.533, \mathrm{p}<0.001\right.$; see also Table $\left.\mathrm{S} 2\right)$. Interestingly, studies of

442 crustaceans tended to be carried out over significantly smaller thermal ranges (mean \pm 95\% C.I.

$443=11.9 \pm 0.8^{\circ} \mathrm{C}$, range $\left.=6.0-22.5^{\circ} \mathrm{C}\right)$ than those of arachnids $\left(20.0 \pm 1.1^{\circ} \mathrm{C}\right.$, range $=12.5-$

$30.0^{\circ} \mathrm{C}$; Tukey’s HSD test, $\left.\mathrm{p}<0.001\right)$ or insects $\left(17.5 \pm 1.2^{\circ} \mathrm{C}\right.$, range $=8.0-38.0$; Tukey’s HSD

$447 \mathrm{p}=0.328)$.

The range of temperatures examined in previous studies was significantly correlated with

451 positively correlated with temperature range were those $(\# 1,2,5-7,13,15$, and 16) that had

452 fewer parameters $(k \leq 4)$ (Fig. 7). This means that these relatively simpler functions tended to do

453 more poorly (higher value = poorer rank, further from 1) when larger thermal ranges were tested.

454 Conversely, rankings of more complex functions with $k=5(\# 20,24$, and 27) or $k=7$ (\#32) were

455 negatively correlated with temperature range (Fig. 7), meaning that these functions performed

456 better (lower value $=$ better rank, closer to 1 ) when studies tested a wider range of temperatures.

\section{4. Discussion:}


4.1. Use and performance of different development functions in previous studies:

462 essential component of studying the biology of poikilothermic organisms (Angilletta Jr., 2006;

463 Bělehrádek, 1935; Papnikolaou et al., 2013; Shi and Ge, 2010). Predictions of generation times

464 (Huntley and Lopez,1992), timing of seasonal events (Bayoh and Lindsay, 2003), dispersal

465 potential (de Rivera et al., 2007), and recruitment to adult populations of Arthropoda (Aiken and

466 Waddy, 1986; Caddy, 1986) produced by such modeling efforts are thus sensitive to the types of

467 temperature-dependent larval development functions incorporated in these. Development times

468 of arthropod larvae predicted for the same species and temperatures by different function types

469 can differ substantially, which has important impacts on predictions made. Using the best

470 possible function to represent a given species' and/or study's dataset should thus be a crucial

471 component of the study of temperature-dependent arthropod larval development, which should

472 precede reporting and use of the results of such studies in models. However, in the present study

473 this important step was found to be largely bypassed by the majority of studies. Particular

474 function types tended to be used more often than others for particular taxonomic groups with

475 little or no clear justification for the choice made, while consideration of alternative function

476 types was rarely reported in published papers. In most cases the function used in original

477 published studies was not actually the best one for the datasets presented. Further, fitting these

478 data with the best model resulted in better fit, less disagreement between predicted and observed

479 development times, decreased information loss, and presumably also better predictive ability.

480 These results demonstrate that development function choice is an important but often-ignored 
481 step in research on arthropod larval development, which should be given greater consideration in 482 future studies.

Choosing one particular development function might have some justification if any

484 function(s) could be said to be better overall than others. In the present study, no single function 485 type was found to be the best or worst, although some did tend to perform better or worse than 486 others (see Fig. 5, 6 in Results). Functions that performed well overall might be recommended as 487 good starting points for fitting development data, and those that did poorly overall could 488 conversely be used with caution. (Table S1). Also, the more complex functions with high $k$ 489 values and including $\mathrm{T}_{\min }$ and $\mathrm{T}_{\max }$ parameters, which performed poorly overall, did somewhat 490 better on insect data than for other taxa and actually was among the best models for some insect 491 species datasets (Table S2). Therefore, it is difficult to make general statements about which 492 function is always best to use; this must rather be assessed on a case-by-case basis, for each 493 species and study. Results in this study showed that not using the best function for a given 494 dataset can result in very different predicted development times, which could lead to very 495 different (and potentially erroneous) inferences and predictions of species biology by modeling 496 studies (Miller et al., 1998; Miller et al., 2006; Quinn, 2014; Reitzel et al., 2004). The practice 497 among many fields of study has been to fit data with a development function type that has been 498 used in previous studies on similar species; for example, the frequent use of the Bĕlehrádek 499 function on copepod crustaceans (Anger, 2001; Corkett and McLaren, 1970; Hamasaki et al. 500 2009) or linear rate + complex function(s) on insects and arachnids (Golizadeh and Zalucki, 501 2012; Shi and Ge, 2010; Smits et al., 2003; Table S2). However, based on results of the present 502 study this practice should be discontinued. 


\subsection{Importance of temperature range tested to function performance:}

An interesting finding in the present study was that overall performance of several function types was correlated with the range of temperatures tested in original published studies. Specifically, as the range of temperatures tested increased performance (i.e., likelihood to be ranked as the best model) of the simpler functions examined decreased while that of more complex functions increased. This result does make sense, however, if one considers the "real" nature of temperature-biological rate relationships. Because the actual performance of the enzymes mediating larval development most certainly have upper and lower functional threshold temperatures, beyond which development cannot progress (Brière et al., 1999; Quinn and Rochette, 2015; Somero, 2004), one can assume that for most species the "true" relationship between temperature and development time resembles the Brière-2 function, or similar complex asymmetrical curves (e.g., Huey and Stevenson, 1979; Shi and Ge, 2010). A study carried out over a very wide range of temperatures should be able to approach or exceed thermal thresholds and therefore identify these limiting temperatures, and thus be best explained by a complex function. However, if one carries out their study over a more narrow thermal range, they will only be able to observe a certain section of the development curve, which could be located relatively far from one or both threshold temperatures. This could result in the observed temperature-development data having a distinctly linear, quadratic, or power function-like shape, such that one of these alternative, simpler functions would be identified as the "best" function for the data over this specific range. Indeed, this seems to have been the case in several of the datasets examined, in which thermal ranges and/or sample sizes were relatively small (e.g., Quinn et al., 2013; Corkett and McLaren, 1970; Hamasaki et al., 2009; Carlotti et al., 2007; Table S1, S2) and the best function was determined to be one of the simpler functions, such as 
527 the linear time (\#6) or Heip power (\#2) function, even though these should be the least-realistic

528 (Bělehrádek, 1935; Brière et al., 1999; Somero, 2004). Importantly, when this occurs the best

529 function will be the one that provides the most informative description of development times

530 over a very specific range of temperatures, but its performance is likely to degrade if

531 extrapolation beyond this range is attempted. Ultimately the "best" function should be of a

532 complex form resembling functions with $\mathrm{T}_{\min }$ and Tmax parameters, but most studies, especially

533 of Crustacea, are not conducted over sufficiently wide temperature ranges to be allow good

534 estimates of such functions' parameters to be derived.

535 The vast majority of insects and arachnids have terrestrial and/or freshwater aquatic

536 habitats, in which temporal variability in air and water temperatures can be very large (Pakyari et

537 al., 2011; Sanchez-Ramos et al., 2007; Stavrinides et al. 2010). As a result, the likelihood of

538 these organisms and their larvae being exposed to extreme temperatures exceeding thresholds for

539 moulting, development, and/or survival can be high. Conversely, many crustaceans (and all of

540 those examined in the present review; Table S2) inhabit the marine realm as larvae and/or adults

541 (Paul and Paul, 1999; Roberts et al., 2012; Thompson, 1982). While it is not impossible that

542 marine crustacean larvae could encounter temperatures too high for development or survival (e.g.,

543 such warm extremes could occur in shallow coastal areas, highly-stratified water columns,

544 intertidal zones at low tide, or more generally due to future climate change; Caffara et al., 2012;

545 Quinn and Rochette, 2015), they are thought to be far more likely to encounter lower limiting

546 temperatures, especially in the deeper ocean or temperate regions (Hartnoll, 1982; MacKenzie,

547 1988; Quinn, 2016). This perceived difference in limiting temperatures appears to have lead

548 studies on temperature-dependent development in these groups along different paths. Studies of

549 insects and arachnids often use very wide temperature ranges with the intent of capturing lower 
550 and upper limiting temperatures for development in their species because these physiological

551 limits are known to be essential to modeling these species in their natural environments (Shi and

552 Ge, 2010; Smits et al., 2003). Studies of crustaceans, to the contrary, tend to be limited to more

553 narrow thermal ranges deemed "ecologically-relevant" (i.e., likely to be encountered by the

554 species in nature); occasionally these include lower limits, but in general physiological limits,

555 especially upper ones, are rarely sought (Hartnoll, 1982; Quinn, 2016).

While there is certainly logic behind the use of narrower, more-relevant thermal ranges in

557 studies of Crustacea, this approach still has potential to result in errors for two main, related

558 reasons. First, the type of development function used changes predicted development times both

559 at and between (interpolation) observed temperatures and especially outside of these

560 (extrapolation) (Angilletta Jr., 2006; Campbell et al., 1974; Quinn and Rochette, 2015). Second,

561 thermal development limits actually change the shape of the "real" and estimated (i.e., fitted by

562 regression) development curve, for example by decreasing its curvature when lower and upper

563 limits are further apart and increasing curvature when these are closer together (Bělehrádek,

564 1935; Brière et al., 1999; Shi and Ge, 2010; personal observations by author). All else being

565 equal, these difference in curvature can result in very different development times at the same

566 temperatures. As a result, it is important to know the physiological limits of a given species when

567 modeling its development (Quinn, 2016). Even if a species rarely encounters temperatures close

568 to these limits, development times calculated at intermediate temperatures will be impacted by

569 the values of these limits; if one ignores these limits and uses a different function type, or

570 attempts to estimate limits by extrapolation from a narrow thermal range, there is great potential

571 for erroneous predictions of development times to be made. 


\subsection{Discussion of potential limitations and next steps:}

In the present review, published studies on arthropod larvae were obtained through literature searches through Web of Science (Thompson Reuters, 2015). These searches were by no means comprehensive - many other studies of temperature-dependent development of arthropod larvae exist that were not indexed in this search engine - but it was extensive and did provide a good sample of such studies encompassing many different years, regions, and arthropod taxa (Table S2). This sample of the relevant literature was thus appropriate and useful for the purposes of the present review of development function usage and performance. An expanded search using additional search tools in a future study could obtained data for other taxonomic groups within the Arthropoda (e.g, myriapods, more arachnids, other orders of Crustacea and Insecta, etc.); indeed, an Insect Developmental Database has been created by Nietschke et al. (2007) that could be used to obtain considerably more insect data for reanalyses. Performance of development functions on data from species outside of the arthropod phylum (e.g., molluscs: de Severyn et al., 2000; nematodes: Jenkins et al., 2006; Singh and Sharma, 1994; urochorates: Kang et al., 2009; vertebrates: McLaren and Cooley, 1972; Miller et al. 2006) may also be attempted, and reveal additional patterns in study design, taxonomy, and function usage of interest. However, overall patterns and conclusions of the present study would likely hold true. To simplify analyses, this study conducted analyses on total larval development time data rather than on individual larval stages. However, in most species development time of each larval stages has a distinct response to temperature, requiring different developmental equations to be derived for each stage (Corkett and McLaren, 1970; Hartnoll, 1982). Often survival to and through later larval stages is very low, so power to fit more complex functions to later-stage development data can be limited. As a result, the best function can potentially differ among 
596 larval stages of the same species, in the same study; indeed, this was noted for American lobster

597 data in the present study (data not shown). A future study should investigate stage-specific

598 changes in the "best" development function(s), to confirm whether such patterns could impact

599 the overall performance of different function types, prediction error, and so on. However, it

600 would make mathematical sense for similar patterns to be found through such a detailed review

601 to those noted in the present study, given that similar factors (e.g., sample sizes and thermal

602 ranges tested) would impact function performance. There are also countless other development

603 function types in existence which were not included in the present study (e.g., Angilletta Jr.,

604 2006; Schoolfied et al., 1981; Shi and Ge, 2010). It is possible that one or more of the functions

605 not examined herein could actually be the closest to "real" development relationships and/or

606 perform better overall than all others. However, findings of this review that one or few functions

607 are used by most studies, the best function was not the one used in most original published

608 studies, and that using the non-best function results in poorer predictions would not change

609 through consideration of such additional functions.

610

In this study function performance was assessed mainly in terms of fit $\left(\mathrm{R}^{2}\right.$ and observed

611 versus predicted values) and information loss $\left(\mathrm{AIC}_{\mathrm{C}}\right.$ and $\left.\Delta_{\mathrm{i}}\right)$. These gave good indications of how

612 appropriate each function and its parameter estimates were for particular datasets (e.g., how well

613 sample sizes supported estimation of more complex functions). However, future studies could

614 take more thorough approaches to assessing predictive ability of different functions. One

615 approach to be used in the future to assess function performance could be cross-validation

616 (Picard and Cook, 1984; Anderson, 2008). Even better would be actually testing development

617 functions on new data, for example by predicting development times for a particular species at

618 different temperatures using different functions derived in a prior study, and then measuring new 
619 development times and comparing these to predictions. If future studies attempted this, very

620 thorough tests and new evidence in favour of one function or another might be obtained.

621

622 4.4. Implications of development time predictions based on different functions:

Differences in development times predicted for the same species and temperature among

624 development functions have potential to impact various types of predictions relevant to arthropod biology and ecology. Larval survival is usually inversely related to larval duration, such that

626 slower development results in fewer potential recruits to adult populations (Reitzel et al., 2004;

627 Roberts et al., 2012). Most life history and bio-physical models account for this by reducing

628 larval numbers in simulated cohorts by a certain percentage at each model time step, resulting in

629 substantial, exponential losses per each additional step spend in larval development (e.g., Miller

630 et al., 1998; Quinn, 2014). In many crustaceans, the larval phase of the life cycle is the main

631 dispersive phase (Anger, 1984; de Rivera et al., 2007; MacKenzie, 1988). Lengthening the larval

632 developmental period of such larvae can dramatically alter how far and to where larvae drift in

633 simulations with ocean currents; for example, simulations by Quinn (2014) showed that slowing

634 larval development (and thus lengthening drift time) of American lobster larvae by $60 \%$ could

635 result in increased drift distances of larvae by up to ca. $500 \mathrm{~km}$. If drift were overestimated in

636 such models, for instance due to use of inappropriate development functions, then the degree of

637 population mixing would be overestimated and an incorrect estimate of population structure

638 obtained; underestimation by the same means could also lead to considerable errors. Likewise if

639 dispersal ability of larvae of an invasive species, such as the green crab Carcinus maenas (L.) (de

640 Rivera et al., 2007), were underestimated in this way potential invasions to new regions that

641 could be predicted may be missed. Using development functions to estimate the timing of 
642 seasonal peaks in abundance of disease vectors (Bayoh and Lindsay, 2003), agricultural pests

643 (Campbell et al., 1994; Easterbrook et al., 2003; Stavrinides et al., 2010), or species that serve as

644 important food sources to others (e.g., copepod secondary productivity in the ocean: Carlotti et

645 al., 2007) also depends on being able to make good estimates of larval development. For many

646 species very small differences in development time similar to the difference in "errors" of best

647 and original studies' functions are enough to dramatically alter the nature and implications of

648 modeled predictions (e.g., $\leq 1-5$ days; Gadino and Walton, 2012). The type of development

649 function used can thus have large impacts on predictions, so it is important that studies attempt to

650 find the best model for their data. Importantly, much research is now being initiated to assess

651 how future climate change will impact many species, including arthropods and their larvae

652 (Caffara et al., 2012; Quinn and Rochette, 2015). Use of non-best development functions within

653 such research clearly could result in erroneous predictions as well and so should be avoided.

4.5. Recommendations and conclusions:

Based on results of this study, it is recommended that future studies examining effects of

657 temperature on development of arthropod larvae consider and attempt to fit multiple alternative

658 development function types to their data to determine the best way to model their results and

659 report that this was attempted. No one function type is better or worse overall, but the range of

660 temperatures to be considered and potential use of results (e.g., for extrapolation to temperatures

661 not observed) can be used as a guide when deciding which functions are most likely to provide

662 good representations of data. In general simpler functions could provide better descriptions of

663 development observed over relatively narrow thermal ranges, but provide poor extrapolation

664 ability. Conversely, wider ranges encompassing lower and/or upper limiting temperatures for 
665 development can support more complex functions, which potentially resemble more closely true

666 enzymatic and biological thermal performance curves (Brière et al., 1999; Somero, 2004) and

667 may allow modeling over all temperatures potentially encountered. Studies on crustaceans in

668 particular should be conducted over wider thermal ranges in the future so that limiting

669 temperatures of these species can be identified and more complex, presumably realistic

670 development functions reliably fit to data for these organisms. Considering different potential

671 function types to find the best for each dataset should lead to better predictions of larval

672 development times in support of subsequent research on these important species.

673

674 Acknowledgements:

675

676 Thanks are due to Rémy Rochette, Joël Chassé, Jeff Houlahan, and Heather Hunt for advice and

677 guidance during this project, and the University of New Brunswick, Saint John Campus, for

678 providing resources that made the review and analyses possible. The author also thanks two

679 anonymous reviewers for providing comments that improved the scope and quality of the

680 manuscript.

681

682 References:

683 Aiken, D.E., Waddy, S.L., 1986. Environmental influence on recruitment of the American lobster, Homarus americanus: a perspective. Can. J. Fish. Aquat. Sci. 43, 2258-2270.

Akaike, H., 1973. Information theory as an extension of the maximum likelihood principle, in: 
Al-Saffar, Z.Y., Grainger, J.N.R., Aldrich, J., 1996. Temperature and humidity affecting development, survival and weight loss of the pupal stage of Drosophila melanogaster, and the influence of alternating temperature on the larvae. J. Therm. Biol. 21, 389-396.

Analytis, S., 1977. Über die relation zwischen biologischer entwicklung und temperatur bei phytopathogenen Pilzen. Phytopath. Z. 90, 64-76.

Analytis, S., 1981. Relationship between temperature and development times in phytopathogenic fungus and in plant pests: a mathematical model. Agric. Res. (Athens). 5, 133-159.

Anderson, D.R., 2008. Model Based Inference in the Life Sciences: A Primer on Evidence. Springer Science+Business Media, LLC, New York.

Anger, K., 1983. Temperature and the larval development of Hyas araneus L. (Decapoda: Majidae); extrapolation of laboratory data to field conditions. J. Exp. Mar. Biol. Ecol. 69, 2013-215.

Anger, K., 1984. Development and growth in larval and juvenile Hyas coarctatus (Decapoda, Majidae) reared in the laboratory. Mar. Ecol. Prog. Ser. 19, 115-123.

Anger, K., 1991. Effects of temperature and salinity on the larval development of the Chinese mitten crab Eriocheir sinensis (Decapoda: Grapsidae). Mar. Ecol. Progr. Ser. 72, 103-110.

Anger, K., 2001. Crustacean Issues 12: The Biology of Decapod Crustacean Larvae. A.A. Balkema, Rotterdam.

Angilletta, Jr., M.J., 2006. Estimating and comparing thermal performance curves. J. Therm. Biol. 31, 541-545.

Bayoh, M.N., Lindsay, S.W., 2003. Effect of temperature on the development of the aquatic stages of Anopheles gambiae sensu stricto (Diptera: Culicidae). Bull. Entomol. Res. 93, 375-381. 
711

712

713

714

715

716

717

718

719

720

721

722

723

724

725

726

727

728

729

730

731

Bělehrádek, J., 1935. Temperature and living matter. Protoplasma Monographia, No. 8.

Borntraeger, Berlin.

Blanckenhorn, W.U., 1997. Effects of temperature on growth, development and diapause in the yellow dung fly - against all the rules? Oecologia 111, 318-324.

Blanco, J. M., Guerrero, F., Rodríguez, V., 1995. The fate of comparisons of models in temperature-dependent growth of copepods: a reply to the comments by McLaren. J. Plankton Res. 17, 1391-1394.

Brière, J.F., Pracross, P., Rioux, A.Y., Pierre, J.S., 1999. A novel rate model of temperaturedependent development for arthropods. Environ. Entomol. 28, 22-29.

Caddy, J.F., 1986. Modelling stock-recruitment processes in Crustacea: some practical and theoretical perspectives. Can. J. Fish. Aquat. Sci. 43, 2330-2344.

Caffara, A., Rinaldi, M., Eccel, E., Rossi, V., Pertot, I., 2012. Modelling the impact of climate change on the interaction between grapevine and its pests and pathogens: European grapevine moth and powdery mildew. Agr. Ecosyst. Environ. 148, 89-101.

Campbell, A., Frazer, B.D., Gilbert, N., Gutierrez, A.P., Mackauer, M., 1974. Temperature requirements of some aphids and their parasites. J. Appl. Ecol. 11, 431-438.

Campolo, O., Malacrinò, A., Laudani, F., Maione, V., Zappalà, L., Palmeri, V., 2014. Population dynamics and temperature-dependent development of Chrysomphalus aonidum (L.) to aid sustainable pest management decisions. Neotrop. Entomol. 43, 453-464.

Carlotti, F., Bonnet, D., Halsband-Lenk, C., 2007. Development and growth rates of Centropages typicus. Progress in Oceanography 72, 164-194. 
732 Cave, R.D., Schiacchetano, C., Diaz, R., 2009. Temperature-dependent development of the

733 cycad Aulacapsis scale, Aulacapsis yasumatsui (Hemiptera: Diaspididae). Florida Entomol. 92, 578-581.

Choy, S., 1991. Embryonic and larval biology of Liocarcinus holsatus and Necora puber (Crustacea: Brachyura: Portunidae). J. Exp. Mar. Biol. Ecol. 148, 77-92.

Cooper, B.S., Tharp II, J.M., Jernberg, I.I., Angilletta Jr., M.J., 2012. Developmental plasticity of thermal tolerances in temperate and subtropical populations of Drosophila melanogaster. J. Therm. Biol. 37, 211-216.

740

741

Corkett, C.J., 1972. Development rate of copepod eggs of the genus Calanus. J. Exp. Mar. Biol. Ecol. 10, 171-175.

Corkett, C.J., McLaren, I.A., 1970. Relationships between development rate of eggs and older stages of copepods. J. Mar. Biol. Assoc. U.K. 50, 161-168.

Coutant, C.C., Talmage, S.S., 1976. Thermal effects. J. Wat. Poll. Contr. Fed. 48, 1486-1544.

Criales, M.M., Anger, K., 1986. Experimental studies on the larval development of the shrimps Crangon crangon and C. allmanni. Helgoländer Meeresun. 40, 241-265.Cummings, G., Fiddler, F., Vaux, D.L., 2007. Error bars in experimental biology. J. Cell Biol. 177, 7-11. Davidson, J., 1942. On the speed of development of insect eggs at constant temperatures. Ayst. J. Exp. Biol. Med. Sci. 20, 233-239.

Dawirs, R.R., 1985. Temperature and larval development of Carcinus maenas (Decapoda) in the laboratory; predictions of larval dynamics in the sea. Mar. Ecol. Progr. Ser. 24, 297-302. de Oliveira, S.A., Souza, B., Auad, A.M., da Silva, D.M., Souza, L.S., Carvalho, C.A., 2009. Desenvolvimento e reprodução de Sipha flava (Forbes) (Hemiptera: Aphididae) em diferentes temperaturas. Neotrop. Entomol. 38, 311-316. 
755

756

757

758

759

760

761

762

763

764

765

766

767

768

769

770

771

772

773

774

775

776

de Rivera, C.E., Hitchcock, N.G., Teck, S.J., Steves, B.P., Hines, A.H., Ruiz, G.M., 2007. Larval development rate predicts range expansion of an introduced crab. Mar. Biol. 150, 12751288.

de Severeyn, Y. G., Severeyn, H., Grant, W., Reverol, Y., 2000. Effect of water temperature on larval development of the bivalve mollusk Tivela mactroides: evaluation in the laboratory and via simulation. Ecol. Model. 129, 143-151.

Du, W.-G., Hu, L.-J., Lu, J.-L., Zhu, L.-J., 2007. Effects of incubation temperature on embryonic development rate, sex ratio and post-hatching growth in the Chinese three-keeled pond turtle, Chinemys reevesii. Aquaculture 272, 747-753.

Easterbrook, M.A., Fitzgerald, J.D., Pinch, C., Tooley, J., Xu, X.-M., 2003. Development time and fecundity of three important arthropod pests of strawberry in the United Kingdom. Ann. Appl. Biol. 143, 325-331.

Edgar, A.J., Andrew, T.E., 1990. A simple method for fitting Bĕlehrádek’s equation to embryonic development data of zooplankton. Hydrobiologia 194, 177-181.

Eliopoulos, P.A., Kontodimas, D.C., Stathas, G.J., 2010. Temperature-dependent development of Chilocorus bipustulatus (Coleoptera: Coccinellidae). Environ. Entomol. 39, 1352-1358.

Emmert, C.J., Mitzell III, R.F., Andersen, P.C., Frank, J.H., Stimac, J.L., 2008. Effects of contrasting diets and temperatures on reproduction and prey consumption by Proprioseiopsis asetus (Acari: Phytoseiidae). Exp. Appl. Acarol. 44, 11-26.

Escribano, R., Rodriguez, L., Irribarren, C., 1998. Temperature-dependent development and growth of Calanus chilensis Brodsky from Northern Chile. J. Exp. Mar. Biol. Ecol. 229, $19-34$. 
777 Forster, J., Hirst, A.G., 2012. The temperature-size rule emerges from ontogenetic difference

778

779

780

781

782

783

784

785

786

787

788

789

790

791

792

793

794

795

796

797

798

between growth and development rates. Functional Ecol. 26, 483-492.

Forster, J., Hirst, A.G., Woodward, G., 2011. Growth and development rates have different thermal responses. Am. Nat. 178, 668-678.

Gadino, A.N., Walton, V.M., 2012. Temperature-related development and population parameters for Typhlodromus pyri (Acari: Phytoseiidae) found in Oregon vineyards. Exp. Appl. Acarol. 58, 1-10.

Gao, G.-Z., Perkins, L.E., Zalucki, M.P., Lu, Z.-Z., Ma, J.-H., 2013. Effect of temperature on the biology of Acyrthosiphon gossypii Mordvilko (Homoptera: Aphididae) on cotton. J. Pest. Sci. 86, 167-172.

Geffen, A.J., Nash, R.D.M., 2012. Egg development rates for use in egg production methods (EPMs) and beyond. Fish. Res. 117-118, 48-62.

Golizadeh, A., Zalucki, M.P., 2012. Estimating temperature-dependent developmental rates of potato tuberworm, Phthorimaea operculella (Lepidoptera: Gelechiidae). Insect Sci. 19, 609-620.

Gonzàlez, L., Carvajal, J., 2003. Life cycle of Caligus rogercresseyi (Copepoda: Caligidae) parasite of Chilean reared salmonids. Aquaculture 220, 101-117.

Greenberg, S.M., Sétamou, M., Sappington, T.W., Liu, T.-X., Coleman, R.J., Armstrong, J.S., 2005. Temperature-dependent development and reproduction of the boll weevil (Coleoptera: Curculionidae). Insect Sci. 12, 449-459.

Guerrero, F., Blanco, J.M., Rodríguez, V., 1994. Temperature-dependent development in marine copepods: a comparative analysis of models. J. Plankton Res. 16, 95-103. 
Haghani, M., Fathipour, Y., Talebi, A.A., Baniameri, V., 2007. Temperature-dependent development of Diglyphus isaea (Hymenoptera: Eulophidae) on Liriomyza sativae (Diptera: Agromyzidae) on cucumber. J. Pest Sci. 80, 71-77.

Hamasaki, K., Sugizaki, M., Dan, S., Kitada, S., 2009. Effect of temperature on survival and developmental period of coconut crab (Birgus latro) reared in the laboratory. Aquaculture 292, 259-263.

Harcourt, D.C., Yee, J.M., 1982. Polynomial algorithm for predicting the duration of insect life stages. Environ. Entomol. 11, 581-584.

Hartnoll, R.G., 1982. Growth, in: The Biology of the Crustacea, Vol. 2: Embryology, Morphology, and Genetics. Abele, L.G. (Ed.). Academic Press, New York, pp. 111-196.

Heip, C., 1974. A comparison between models describing the influence of temperature on the development rate of copepods. Biologisch Jaarboek Dodonaea 42, 121-125.

Herzig, A., 1983. The ecological significance of the relationship between temperature and duration of embryonic development in planktonic freshwater copepods. Hydrobiologia $100,65-91$.

Hilbert, D.W., Logan, J.A., 1983. Empirical model of nymphal development for the migratory grasshopper, Melanoplus sanguinipes (Orthoptera: Acrididae). Environ. Entomol. 12, 1-5.

Holling, C.S., 1965. The functional response of predators to prey density and its role in mimicry and population regulation. Mem. Entomol. Soc. Can. 45, 1-60.

Huang, Z., Ren, S., Musa, P.D., 2008. Effects of temperature on development, survival, longevity, and fecundity of the Bemisia tabaci Gennadius (Homoptera: Aleyrodidae) predator, Axinoscymnus cardilobus (Coleoptera: Coccinellidae). Biol. Control 46, 209215. 
822 Huey, R.b., Svenson. R.D., 1979. Integrating thermal physiology and ecology of ectotherms: a

823

824

825

826

827

828

829

830

831

832

833

834

835

836

837

838

839

840

841

842

843 discussion of approaches. Am. Zool. 19, 357-366.

Huntley, M.E., López, M.D.G., 1992. Temperature-dependent production of marine copepods: a global synthesis. Am. Nat. 140, 201-242.

Ikemoto, T., Takai, K., 2000. A new linearized formula for the law of total effective temperature and the evaluation of line-fitting methods with both variables subject to error. Environ. Entomol. 29, 671-682.

Ismael, D., Anger, K., Moreira, G.S., 1997. Influence of temperature on larval survival, development, and respiration in Chasmagnathus granulata (Crustacea, Decapoda). Helgoländer Meeresun. 52, 463-475.

Jacas, J.A., Peña, J.E., Duncan, R.E., Ulmer, B.J., 2008. Thermal requirements of Fidiobia dominica (Hymenoptera: Platygastridae) and Haeckeliania sperata (Hymenoptera: Trichogrammatidae), two exotic egg parasitoids of Diaprepes abbreviatus (Coleoptera: Curculionidae). BioControl 53, 451-460.

Jaffari, S., Fathipour, Y., Faraji, F., 2012. Temperature-dependent development of Neoseiulus barkeri (Acari: Phytoseiidae) on Tetranychus urticae (Acari: Tetranychidae) at seven constant temperatures. Insect Sci. 19, 220-228.

Janisch, E., 1932. The influence of temperature on the life-history of insects. Trans. Entomol. Soc. Lond. 80, 137-168.

Jenkins, E. J., Kutz, S.J., Hoberg, E.P., Polley, L., 2006. Bionomics of larvae of Parelaphostronglyus odocoilei (Nematoda: Protostrongylidae) in experimentally infected gastropod intermediate hosts. J. Parasitol. 92, 298-305. 
844 Kamps, D.M., 1978. The effect of temperature on the development time and brood size of

845

846

847

848

849

850

851

852

853

854

855

856

857

858

859

860

861

862

863

864

865
Diaptomus pallidus Herrick. Hydrobiologia 61, 75-80.

Kang, K.H., Zhang, Z.F., Bao, Z.M., Zhou, B., Han, C.B., 2009. Influence of water temperature on spawning induction and larval development of the sea squirt Halocynthia ritteri (Oka, 1906). Aquaculture Res. 40, 513-518.

Karimi-Malati, A., Fathipour, Y., Talebi, A.A., 2014. Development response of Spodoptera exigua to eight constant temperatures: Linear and nonlinear modeling. J. Asia-Pac. Entomol. 17, 349-354.

Khan, M., Gregg, P., Mensah, R., 2009. Effect of temperature on the biology of Creontiades dilutus (Heteroptera: Miridae). Austral. J. Entomol. 48, 210-216.

Kim, D.-S., Riedl, H., 2005. Effect of temperature on development and fecundity of the predaceous plant bug Deraeocoris brevis reared on Ephestia kuehniella eggs. BioControl $50,881-897$.

Kim, S.C., Song, J.-H., Kim, D.-S., 2008. Effect of temperature on the development and fecundity of the Cryptic Mealybug, Pseudococcus cryptus, in the laboratory. J. Asia-Pac. Entomol. 11, 149-153.

Klein Breteler, W.C.M., Gonzalez, S.R., Schogt, N., 1995. Development of Pseudocalanus elongatus (Copepoda, Calanoida) cultured at different temperatures and food conditions. Mar. Ecol. Prog. Ser. 119, 99-110.

Koda, K., Nakamura, H., 2010. Effects of temperature on the development and survival of an endangered butterfly, Shijimiaeoides divinus barine (Leech) (Lepidoptera: Lycaenidae). Entomol. Sci. 13, 29-34. 
866

867

868

869

870

871

872

873

874

875

876

877

878

879

880

881

882

883

884

885

886

Kontodimas, D.C., Eliopoulos, P.A., Stathas, G.J., Economou, L.P., 2004. Comparative temperature-dependent development of Nephus includens (Kirsch) and Nephus bisignatus (Boheman) (Coleoptera: Coccinellidae), preying on Planococcus citri (Risso) (Homoptera: Pseudococcidae): evaluation of a linear and various non-linear models using specific criteria. Environ. Entomol. 33, 1-11.

Krüger, R.F., Kirst, F.D., de Souza, A.S.B., 2010. Rate of development of forensically-important Diptera in southern Brazil. Revista Brasileira de Entomologia 54, 624-629.

Lactin, D.J., Holliday, N.J., Johnson, D.L., Craigen, R., 1995. Improved rate model of temperature-dependent development by arthropod. Environ. Entomol. 24, 68-75.

Lamb, R.J., Gerber, G.H., Atkinson, G.F., 1984. Comparison of developmental rate curves applied to egg hatching data of Entomoscelis Americana Brown (Col: Chrysomelidae). Environ. Entomol. 13, 868-872.

Lavagnini, T.C., de Freitas, S., Bezerra, A.L., 2009. Aspectos biológicos de Chrysoperla raimundoi Freitas \& Penny (Neuroptera, Chrysopidae). Revista Brasileira de Entomologia 53, 629-634.

Lefebvre, F., Pasquerault, T., 2004. Temperature-dependent development of Ophyra aenescens (Wiedemann, 1830) and Ophyra capensis (Wiedemann, 1818) (Diptera, Muscidae). Forensic Sci. Int. 139, 75-79.

Li, D., 2002. The combined effects of temperature and diet on development and survival of a crab spider, Misumenops tricuspidatus (Fabricius) (Araneae: Thomisidae). J. Therm. Biol. 27, 83-93. 
Lind, M.I., Johansson, F., 2007. The degree of adaptive phenotypic plasticity is correlated with the spatial environmental heterogeneity experienced by island populations of Rana temporaria. J. Evo. Biol. 20, 1288-1297.

Lindley, J.A., 1990. Regressions for estimating development times of the pelagic larvae of Paguridae and Porcellanidae. J. Plankton Res. 12, 673-678.

Liu, S.-S., Meng, X.-D., 1999. Modelling development time of Myzus persicae (Hemiptera: Aphididae) at constant and natural temperatures. Bull. Entomol. Res. 89, 53-63.

Logan, D.P., Kettle, C.G., 2007. Temperature-dependent development and distribution in the soil profile of pupae of greyback canegrub Dermolepida albohirtum (Waterhouse) (Coleoptera: Scarabaeidae) in Queensland sugarcane. Austral. J. Entomol. 46, 17-22.

Logan, J.A., 1988. Toward an expert system for development of pest simulation models. Environ. Entomol. 17, 359-376.

Logan, J.A., Wollkind, D.J., Hoyt, S.C., Tanigoshi, K., 1976. An analytical model for description of temperature dependent rate phenomena in arthropods. Environ. Entomol. 5, 1133-1140.

Luypaert, G., Witters, J., Huylenbroeck, J.V., Maes, M., De Riek, J., De Clercq, P., 2014. Temperature-dependent development of the broad mite Polyphagotarsonemus latus (Acari: Tarsonemidae) on Rhododendron simsii. Exp. Appl. Acarol. 63, 389-400.

MacKenzie, B.R., 1988. Assessment of temperature effects on interrelationships between stage durations, mortality, and growth in laboratory-reared Homarus americanus Milne Edwards larvae. J. Exp. Mar. Biol. Ecol. 116, 87-98.

Marchioro, C.A., Forester, L.A., 2011. Development and survival of the diamondback moth, Plutella xylostella (L.) (Lepidoptera: Yponomeutidae) as a function of temperature: 
effects of number of generations in tropical and subtropical regions. Neotrop. Entomol. 40, 533-541.

Matsuda, H., Yamakawa, T., 1997. Effects of temperature on growth of the Japanese spiny lobster, Panulirus japonicus (V. Siebold) phyllosomas under laboratory conditions. Mar. Freshwater Res. 48, 791-796.

Mazzei, K.C., Newman, R.M., Loos, A., Ragsdale, D.W., 1999. Development rates of the native milfoil weevil, Eurhychiopsis lecontei, and damage to Eurasian watermilfoil at constant temperatures. Biol. Control 16, 139-143.

McLaren, I.A., 1963. Effects of temperature on growth of zooplankton and the adaptive value of vertical migration. J. Fish. Res. Board Can. 20, 685-727.

McLaren, I.A., 1995. Temperature-dependent development in marine copepods: comments on choices of models. J. Plankton Res. 17, 1385-1390.

McLaren, I.A., Cooley J.M., 1972. Temperature adaptation of embryonic development rate among frogs. Physiol. Zool. 45, 223-228.

McLaren, I.A., Corkett, C.J., Zillioux, E.J., 1969. Temperature adaptations of copepod eggs from the Arctic to the Tropics. Biol. Bull. 137, 486-493.

McQuaid, C.D., Branch, G.M., 1985. Trophic structure of rocky intertidal communities: response to wave action and implications for energy flow. Mar. Ecol. Prog. Ser. 22, 153-161.

Mehrnejad, M.R., 2012. Biological parameters of Elasmus nudus (Hymenoptera, Eulophidae), a parasitoid of the pistachio fruit hull borer moth, Arimania komaroffi (Lepidoptera, Pyralidae). Biocontrol Sci. Technol. 22, 659-670.

Menge, B.A., 1978. Predation intensity in a rocky intertidal community: effect of an algal canopy, wave action and desiccation on predator feeding rates. Oecologia 34, 17-35. 
Miller, C.B., Lynch, D.R., Carlotti, F., Gentleman, W., Lewis, C.V.W., 1998. Coupling of an individual-based population dynamic model of Calanus finmarchicus to a cricualtion model for the Georges Bank region. Fish. Oceanogr. 7, 219-234.

Miller, D.C.M., Moloney, C.L., van der Lingen, C.D., Lett, C., Mullon, C., Field, J.G., 2006. Modelling the effects of physical-biological interactions and spatial variability in spawning and nursery areas on transport and retention of sardine Sardinops sagax eggs and larvae in the southern Benguela ecosystem. J. Mar. Syst. 61, 212-229.

Milne Edwards, H., 1837. Histoire naturelle des Crustacés, comprenant l'anatomie, la physiologie et la classification de ces animaux. Volume 2. Librairie encyclopédique de Roret, Paris.

Mironidis, G.K., Savopoulou-Soultani, M., 2009. Development, survival and growth rate of the Hyposoter didymator-Helicoverpa armigera parasitoid-host system: effect of host instar at parasitism. Biol. Control 49, 58-67.

Mobarakian, M., Zamani, A.A., Karmizadeh, J., Naghadeh, N.M., Emami, M.S., 2014. Modelling development of Callosobruchus maculatus and Anisopteromalus calandrae at various constant temperatures using linear and non-linear models. Biocontrol Sci. Tech. 24, 1308-1320.

Mochizuki, S., Kayaba, Y., Tanida, K., 2006. Larval growth and development in the caddisfly Cheumatopsyche brevilineata under natural thermal regimes. Entomol. Sci. 9, 129-136.

Mols, P.J.M., van de Ende, E., Blommers, L.H.M., 1998. Embryonic and larval development of Orthosia (Lep., Noctuidae) species used for optimizing timing of monitoring and control in apple orchards. J. Appl. Entomol. 122, 431-439. 
Morimoto, S., Imamura, T., Visarathanonth, P., Miyanoshita, A., 2007. Effects of temperature on the development and reproduction of the predatory bug Joppeicus paradoxus Puton (Hemiptera: Joppeicidae) reared on Tribolium confusum eggs. Biol. Control 40, 136-141.

Naish, P.J., Hartwell, S., 1988. Exponentially modified Gaussian functions - a good model for chromatographic peaks in isocratic HPLC? Chromatographia 26, 285-296.

Newman, B.K., Papadopoulos, I., Vorsatz, J., Woolridge, T.H., 2006. Influence of temperature on the larval development of Upogebia africana and U. capensis (Decapoda: Thalassinidae: Upogebiidae) in the laboratory. Mar. Ecol. Prog. Ser. 325, 165-180.

Nietschke, B.S., Magarey, R.D., Borchert, D.M., Calvin, D.D., Jones, E., 2007. A developmental database to support insect phenology models. Crop Protect. 26, 1444-1448.

Nondillo, A., Redaelli, L.R., Botton, M., Pinent, S.M.J., Gitz, R., 2008. Exigências Térmicas e Estimativa do Número de Gerações Anuais de Frankliniella occidentalis (Pergande) (Thysanoptera: Thripidae) em Morangueiro [Thermal Requirements and Estimate of the Annual Number of Generations of Frankliniella occidentalis (Pergande) (Thysanoptera: Thripidae) on Strawberry Crop]. Neotrop. Entomol. 37, 646-650.

Pakyari, H., Fathipour, Y., Enkegaard, A., 2011. Estimating development and temperature thresholds of Scholothrips longicornis (Thysanoptera: Thripidae) on eggs of two-spotted spider mite using linear and nonlinear models. J. Pest Sci. 84, 153-163.

Palmer, M.A., Coull, B.C., 1980. The prediction of development rate and the effect of temperature for the meiobenthic copepod, Microarthridion littorale (Poppe). J. Exp. Mar. Biol. Ecol. 48, 73-83.

Papanikolaou, N.E., Milonas, P.G., Kontodimas, D.C., Demiris, N., Matsinos, Y.G., 2013. Temperature-dependent development, survival, longevity and fecundity of the 
aphidophagous ladybird beetle, Propylea quatuordecimpunctata (Coleoptera:

979 Park, H.-H., Ahn, J.-J., Park, C.-G., 2014. Temperature-dependent development of

980 Cnaphalocrocis medianalis Guenée (Lepidoptera: Pyralidae) and their validation in semifield conditions. J. Asia-Pac. Entomol. 17, 83-91.

982 Paul, A.J., Paul, J.M., 1999. Development of larvae of the golden king crab Lithodes aequispinus (Anomura: Lithodidae) reared at different temperatures. J. Crustac. Biol. 19, 42-45.

Picard, R., Cook, D., 1984. Cross-validation of regression models. J. Am. Stat. Assoc.79, 575583.

986 Prasad, Y.G., Prabhakar, M., Sreedevi, G., Rao, G.R., Venkateswarlu, B., 2012. Effect of temperature on development, survival and reproduction of mealybug, Phenacoccus solenopsis Tinsley (Hemiptera: Pseudococcidae) on cotton. Crop Protect. 39, 81-88.

Quinn, B.K., 2014. Assessing potential influence of larval development time and drift on largescale spatial connectivity of American lobster (Homarus americanus). M.Sc. Thesis, University of New Brunswick, Saint John, NB.

Quinn, B.K., 2016 (in press). Threshold temperatures for performance and survival of American lobster larvae: a review of current knowledge and implications to modeling impacts of climate change. Fish. Res. http://dx.doi.org/10.1016/j.fishres.2016.09.022. 
Quinn, B.K., Rochette, R., Ouellet, P., Sainte-Marie, B., 2013. Effect of temperature on development rate of larvae from cold-water American lobster (Homarus americanus). J. Crustac. Biol. 33, 527-536.

Ramalho, F.S., Wanderley, P.A., Malaquias, J.B., Rodrigues, K.C.V., Souza, J.V.S., Zanuncio, J.C., 2009. Temperature-dependent development rates of Bracon vulgaris, a parasitoid of boll weevil. Phytoparasitica 37, 17-25.

Ratkowsky, D.A., Lowry, R.K., McMeekin, T.A., Stokes, A.N., Chandler, R.E., 1983. Model for bacterial culture growth rate throughout the entire biokinetic temperature range. J. Bacteriol. 154, 1222-1226.

Reitzel, A.M., Miner, B.G., McEdward, L.R., 2004. Relationships between spawning date and larval development time for benthic marine invertebrates: a modeling approach. Mar. Ecol. Prog. Ser. 280, 13-23.

Roberts, S.D., Dixon, C.D., Andreacchio, L., 2012. Temperature dependent larval duration and survival of western king prawn, Penaeus (Melicertus) latisulcatus Kishinouye, from Spencer Gulf, South Australia. J. Exp. Mar. Biol. Ecol. 411, 14-22.

Rothlisberg, P.C., 1979. Combined effects of temperature and salinity on the survival and growth of the larvae of Pandalus jordani (Decapoda: Pandalidae). Mar. Biol. 54, 125-134.

Roy, M., Brodeur, J., Cloutier, C., 2002. Relationship between temperature and development rate of Stethorus punctillum (Coleoptera: Coccinellidae) and its prey Tetranychus mcdaniali (Acarina: Tetranychidae). Environ. Entomol. 31, 177-187.

Sànchez-Ramos, I., Àlvarez-Alfageme, F., Castañera, P., 2007. Development and survival of the cheese mites, Acarus farris and Tyrophagus neiswanderi (Acari: Acaridae), at constant temperatures and 90\% relative humidity. J. Stored Products Res. 43, 64-72. 
Schoolfield, R.M., Sharpe, P.J.H., Magnuson, C.E., 1981. Non-linear regression of biological temperature-depednent rate models based on absolute reaction-rate theory. J. Theor. Biol. $88,719-731$.

Schultze, K., Anger, K., 1997. Larval growth patterns in the Aesop shrimp Pandalus montagui. J. Crustac. Biol. 17, 471-479.

Sharpe, P.J.H., DeMichele, D.W., 1977. Reaction kinetics of poikilotherms development. J. Theor. Biol. 64, 649-670.

Shi, P., Ge, F., 2010. A comparison of different thermal performance functions describing temperature-dependent development rates. J. Therm. Biol. 35, 225-231.

Singh, M., Sharma, S.B., 1994. Temperature effects on development and reproduction of Heterodera cajani on Pigeonpea. J. Nematol. 26, 241-248.

Smits, N., Brière, J.-F., Fargues, J., 2003. Comparison of non-linear temperature-depednent development rate models applied to in vitro growth of entomopathogenic fungi. Mycol. Res. 107, 1476-1484.

Somero, G.N., 2004. Adaptation of enzymes to temperature: searching for basic "strategies". Comp. Biochem. Phys. B 139, 321-333.

Son, Y., Lewis, E.E., 2005. Modelling temperature-dependent development and survival of Otiorhynchus sulcatus (Coleoptera: Curculinonidae). Agr. Forest Entomol. 7, 201-209.

Stavrinides, M.E., Lara, J.R., Mills, N.J., 2010. Comparative influence of temperature on development and biological control of two common vineyard pests (Acari: Tetranychidae). Biol. Control 55, 126-131.

Stinner, R.E., Guitierez, A.P., Butler, Jr., G.D., 1974. An algorithm for temperature-dependent growth rate simulation. Can. Entomol. 106, 519-524. 
1044 1045

1046

1047

1048

1049

1050

1051

1052

1053

1054

1055

1056

1057

1058

1059

1060

1061

1062

1063

1064

1065

Tauti, M., 1925. J. Imp. Fish Inst. Tokyo, 21, (cited in Winberg, 1971 and Guerrero et al., 1994).

Taveras, R., Hilje, L., Carballo, M., 2004. Development of Hypsipyla grandella (Zeller)

(Lepidoptera: Pyralidae) in response to constant temperatures [Desenvolvimento de Hypsipyla grandella (Zeller) (Lepidoptera: Pyralidae) em diferentes temperaturas constants]. Neotrop. Entomol. 33, 1-6.

Taylor, F., 1981. Ecology and evolution of physiological time in insects. Am. Nat. 117, 1-23.

Thessalou-Legaki, M., 1990. Advanced larval development of Callianassa tyrrhena (Decapoda: Thalassinidea) and the effect of environmental factors. J. Crustac. Biol. 10, 659-666.

Thompson, B.M., 1982. Growth and development of Pseudocalanus elongatus and Calanus sp. In the laboratory. J. Mar. Biol. Assoc. U.K. 62, 359-372.

Tofangsazi, N., Buss, E.A., Meagher, R., Mascarin, G.M., Arthurs, S.P., 2012. Thermal requirements and development of Herpetogramma phaeopteralis (Lepidoptera: Crambidae: Spilomelinae). J. Econ. Entomol. 105, 1573-1580.

Tun-Lin, W., Burkot, T.R., Kay, B.H., 2000. Effects of temperature and larval diet on development rates and survival of the dengue vector Aedes aegypti in north Queensland, Australia. Medical and Vet. Entomol. 14, 31-37.

Ulmer, B.J., Jacas, J.A., Peña, J.E., Duncan, R.E., Castillo, J., 2006. Effect of temperature on life history of Aprostocetus vaquitarum (Hymenoptera: Eulophidae), an egg parasitoid of Diaprepes abbreviatus (Coleoptera: Curculionidae). Biol. Control 39, 19-25.

Voss, S.C., Cook, D.F., Hung, W.-F., Dadour, I.R., 2012. Survival and development of the forensically important blow fly, Calliphora varifrons (Diptera: Calliphoridae) at constant temperatures. Forensic Sci. Med. Pathol. 10, 314-321. 
1066

1067

1068

1069

1070

1071

1072

1073

1074

1075

1076

1077

1078

1079

1080

1081

1082

1083

1084

1085

1086

1087

Wang, R.-S., Lan, Z.-X., Ding, Y.-Q., 1982. Studies on mathematical models of the relationship between insect development and temperature. Acta. Ecol. Sin. 2, 47-57. [In Chinese]

Winberg, G.G., 1971. Methods for the Estimation of Production of Aquatic Animals. Academic Press, London.

Yao, S., Huang, Z., Ren, S., Mandour, N., Ali, S., 2011. Effects of temperature on development, survival, longevity, and fecundity of Serangium japonicum (Coleoptera: Coccinellidae), a predator of Bemisia tabaci Gennadius (Homoptera: Aleyrodidae). Biocontrol Sci. Technol. 21, 23-34.

Zhao, F., Zhang, W., Hoffman, A.A., Ma, C.-S., 2014. Night warming on hot days produces novel impacts on development, survival and reproduction in a small arthropod. J. Anim. Ecol. 83, 769-778.

\section{Electronic Supplementary Material:}

Table S1. Development function parameter estimates, $\mathrm{R}^{2}$, and $\mathrm{AIC}_{\mathrm{C}}$ for American lobster data plotted in Figure 1. 
1088 Table S2. List of studies and species obtained for the literature review and meta-analyses,

1089 including taxonomic grouping, function type(s) used, best function, whether the best and used

1090 function were the same, temperature range tested, performance $\left(\mathrm{R}^{2}, \mathrm{AIC}_{\mathrm{C}}\right.$ rank, and $\left.\Delta_{\mathrm{i}}\right)$ of each

1091 of the 33 functions tested ('na' = study not possible to retested in meta-analysis), and

1092 consequences of using original studies' rather than the actual best function to fit datasets in terms

1093 of prediction error, $\mathrm{R}^{2}$ decrease, and information loss $\left(\Delta_{\mathrm{i}}\right)$.

1094

1095

1096

1097

1098

1099

1100

1101

1102

1103

1104

1105

1106

Tables and Figures: 


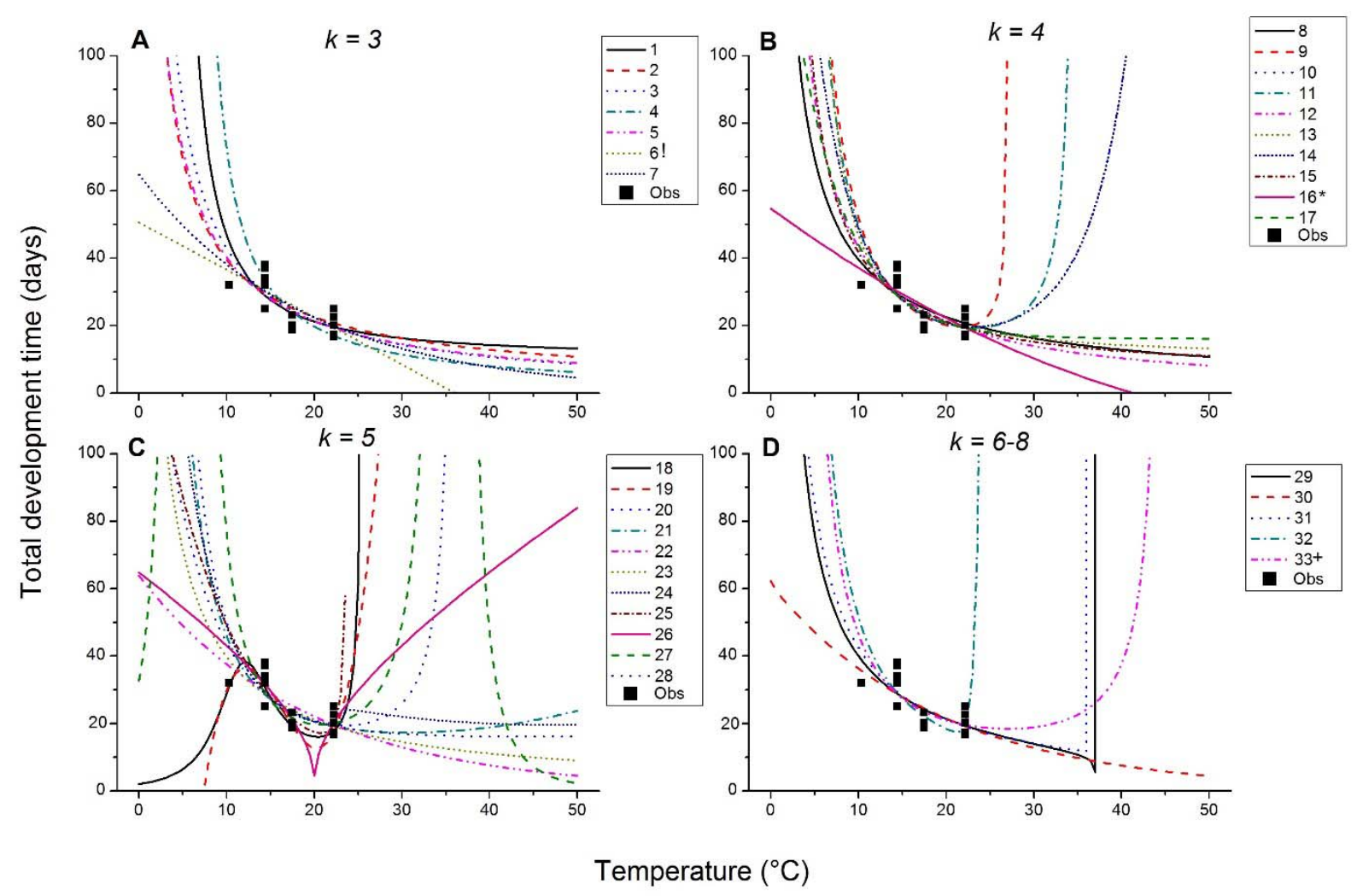

1108 Figure 1. Examples of the curves formed by different development functions, when these are

1109 used to calculate development time (y-axes, days) at different temperatures (x-axes, $\left.{ }^{\circ} \mathrm{C}\right)$. Types

1110 of functions plotted here are those presented in Table 1, separated into those with $k$-values

1111 (number of parameters + 1) of (A) 3, (B) 4, (C) 5, or (D) 6-8. Actual functions (see Table S1)

1112 were derived from and fitted to data for total development times (combined time to complete

1113 larval stages I-III) of American lobster (Homarus americanus (H. Milne Edwards, 1837)) larvae,

1114 as reported by Quinn et al. (2013); observed development times are plotted (squares) along with

1115 predictions of development functions (lines). Coefficients, $\mathrm{R}^{2}, \mathrm{AIC}_{\mathrm{C}}$, and $\Delta_{\mathrm{i}}$ values for these

1116 functions are presented in Table S1. '*' = function used by Quinn et al. (2013) to fit the data, '!'

1117 = actual "best" function for these data, and 't' = worst function for these data. 


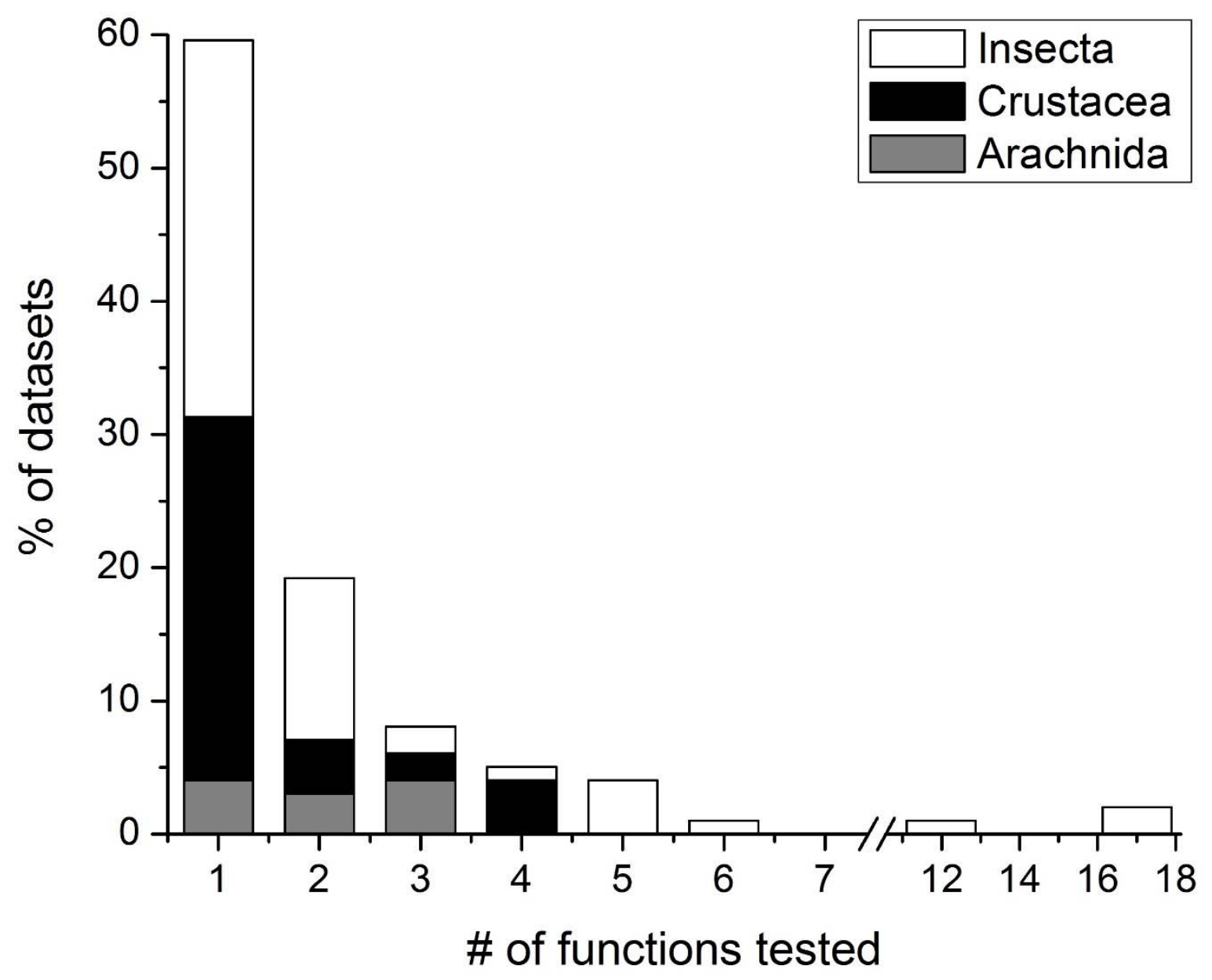

1120 Figure 2. Usage in each development study reviewed of one or more different types of

1121 development function. The percentage (\%) of species datasets obtained in initial literature review

$1122(\mathrm{n}=99$ total, see Table S2) that were tested with each number of functions is plotted on the $y-$

1123 axes and broken down by taxa (gray bars = arachnids, black = crustaceans, and white $=$ insects).

1124 For names and details of development functions (\#1-33) the reader is referred to Table 1. 


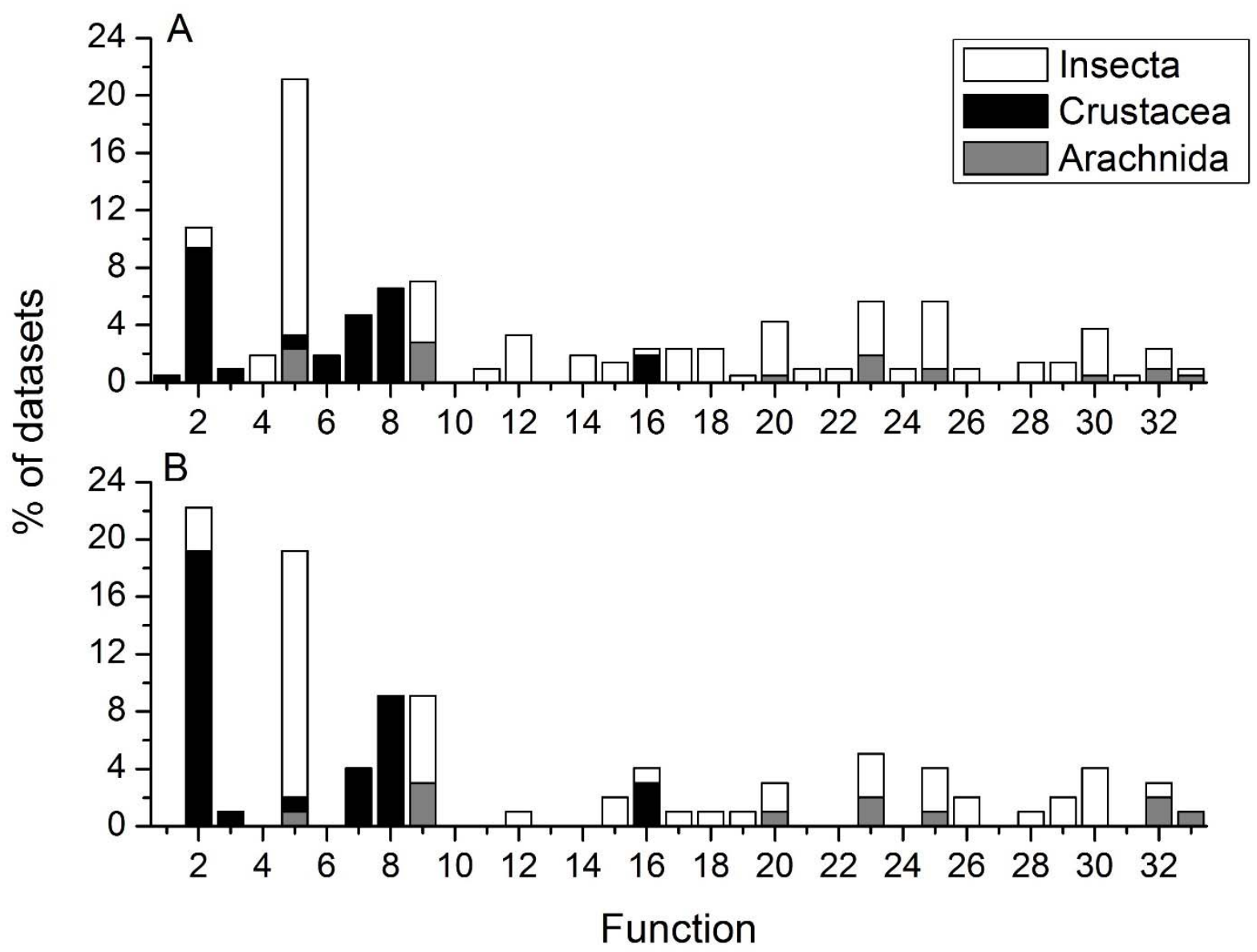

1127 Figure 3. Usage in each development study reviewed of specific development function types.

1128 The percentage (\%) of the 99 species datasets obtained in initial literature review (see Table S2)

1129 that were (A) tested with each type of function (i.e., all used functions) and (B) concluded to be

1130 best represented by each type of function (i.e., best used function) is plotted on the y-axes.

1131 Results are also broken down by taxonomic group, as in Fig. 2. For names and details of

1132 development functions (\#1-33) the reader is referred to Table 1. 


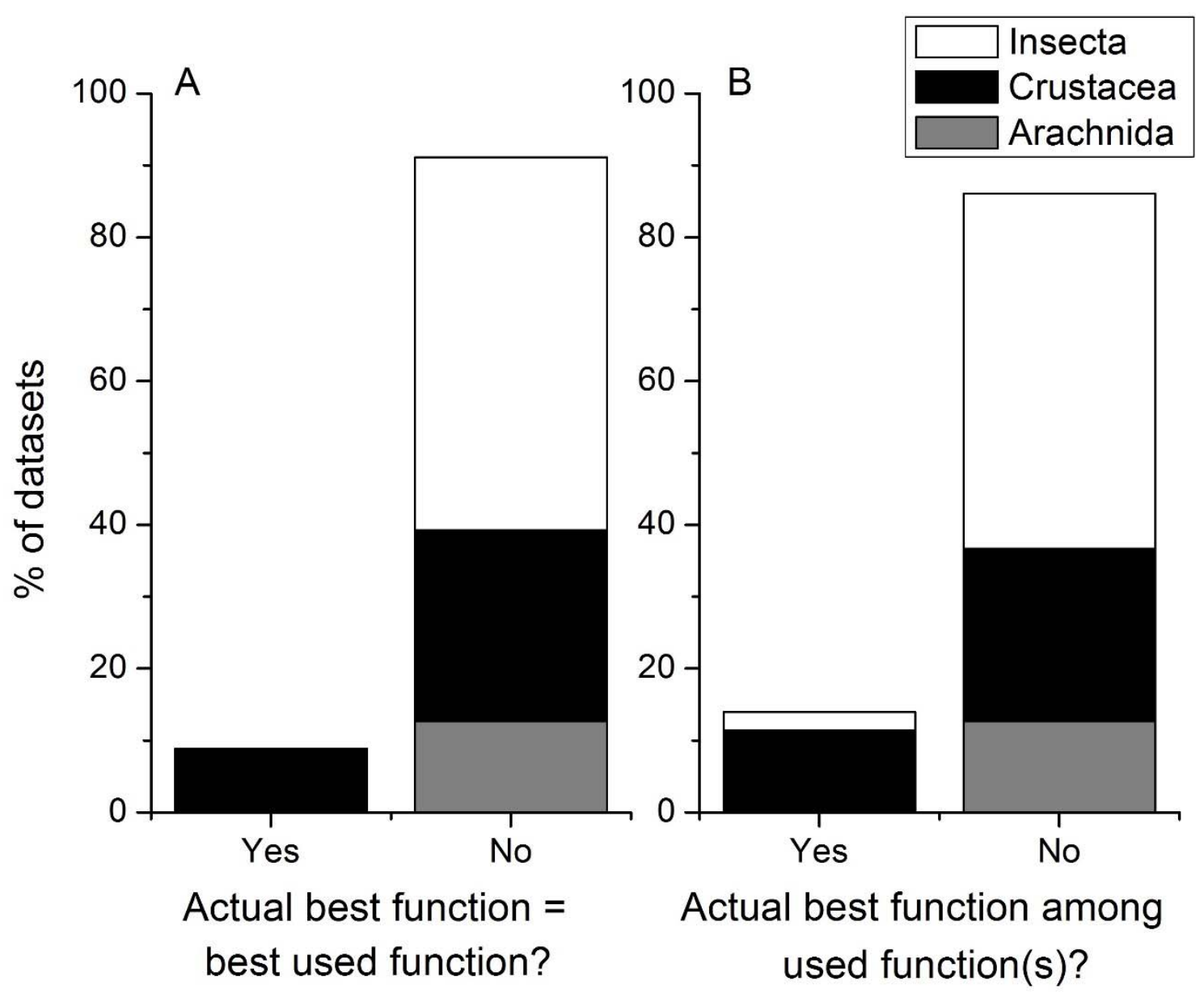

1135 Figure 4. Percentage $(\%)$ of species datasets re-analyzed for meta-analysis $(\mathrm{n}=79)$ for which the 1136 development function found to be best for the data (lowest $\mathrm{AIC}_{\mathrm{C}}$ value, ranking based on $\mathrm{AIC}_{\mathrm{C}}=$ 1137 1) in this study (i.e., actual best function) (A) agreed or not with the best function as used in its 1138 original published study or (B) was among the set of all function(s) used within its original 1139 published study. Results are also broken down by taxonomic group, as in Fig. 2. For names and 1140 details of development functions (\#1-33) the reader is referred to Table 1. 


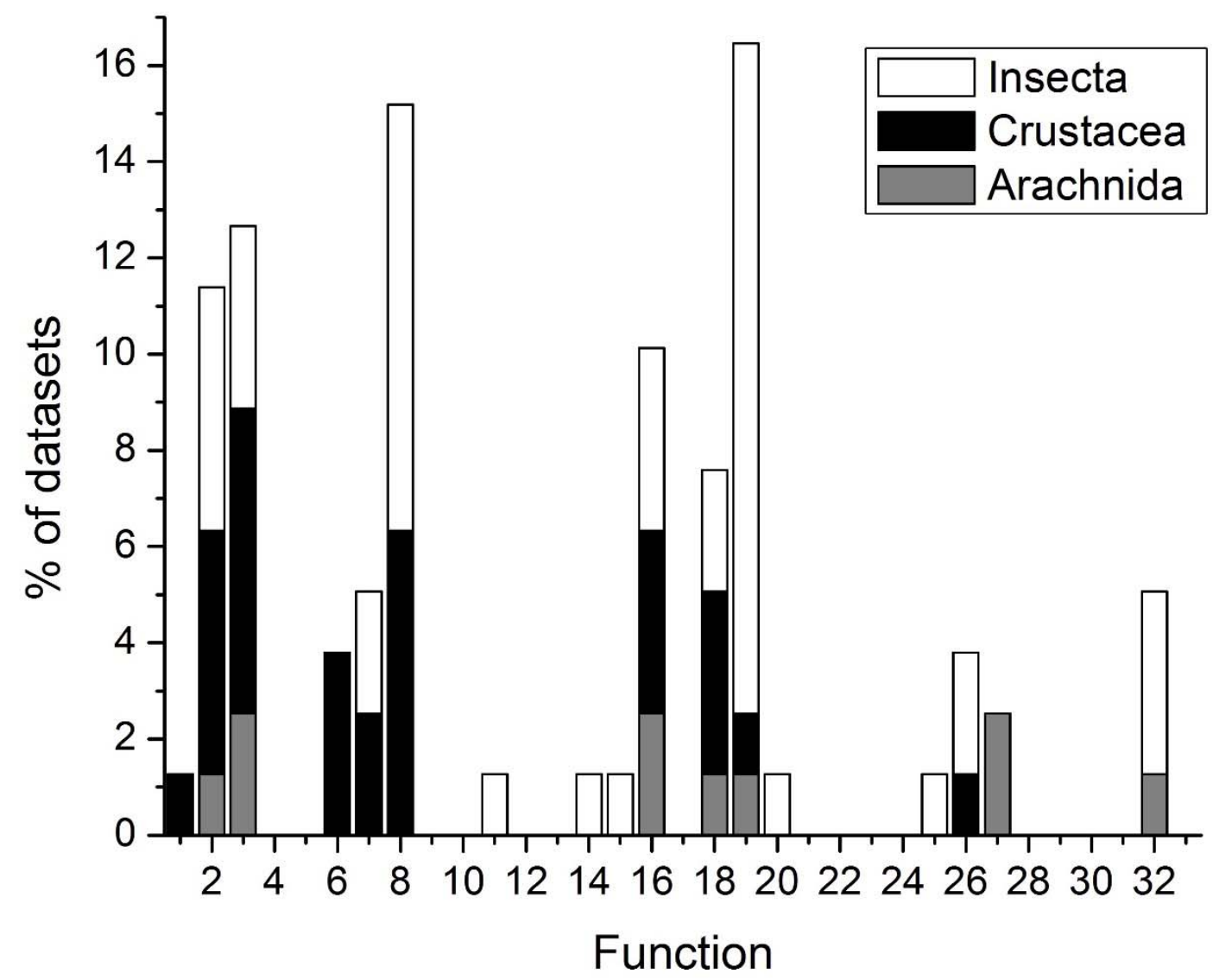

1143 Figure 5. Percentage $(\%)$ of species datasets re-analyzed for meta-analysis $(n=79)$ for which

1144 each development function type was found to be best for the data (lowest $\mathrm{AIC}_{\mathrm{C}}$ value, ranking

1145 based on $\mathrm{AIC}_{\mathrm{C}}=1$ ) in this study. Results are broken down by taxonomic group, as in Fig. 2. For

1146 names and details of development functions (\#1-33) the reader is referred to Table 1. 

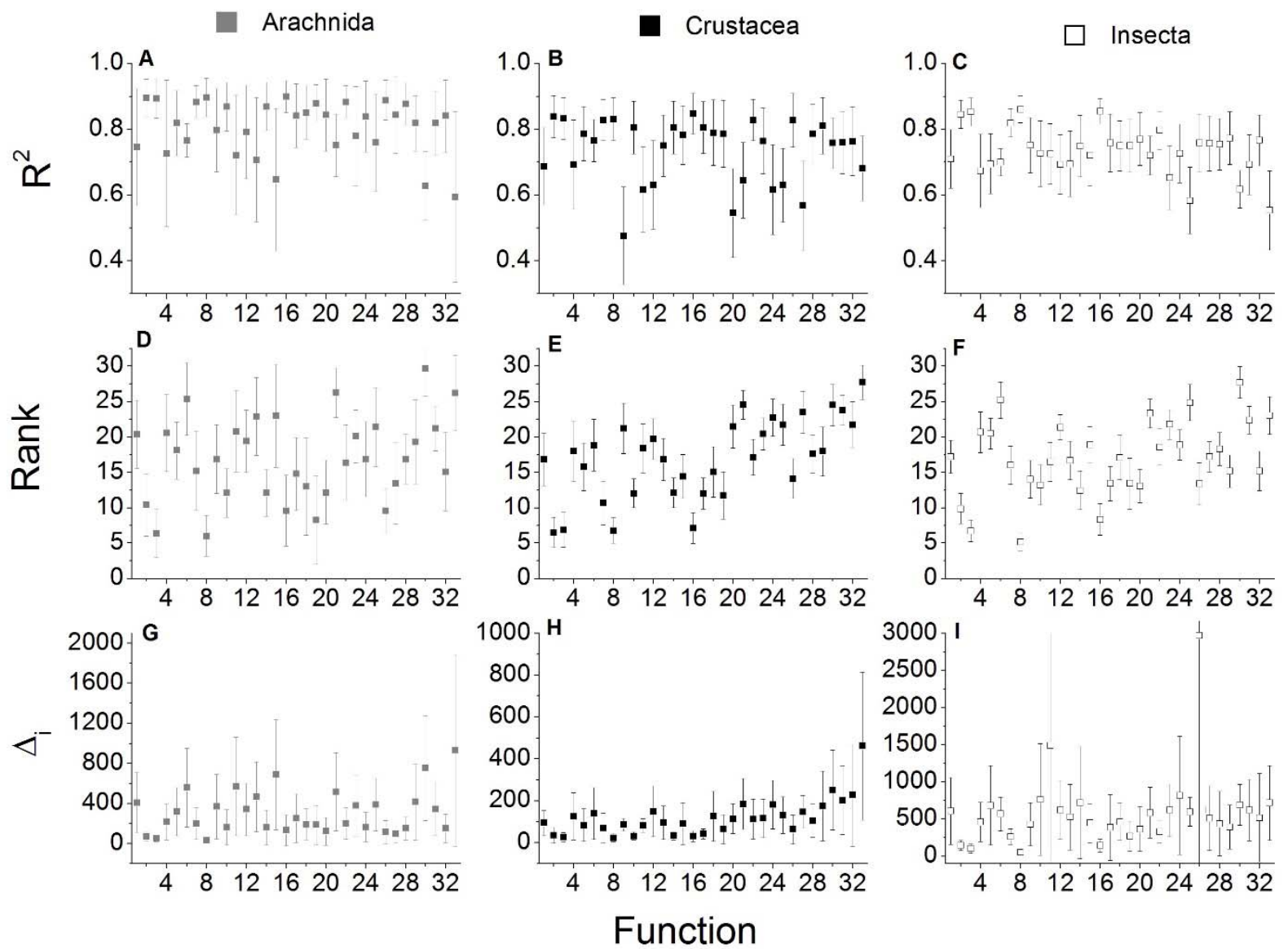

1149 Figure 6. Overall performance of different development functions (x-axes) assessed based on

1150 (A-C) $R^{2}$ values, (D-F) ranking based on $\mathrm{AIC}_{\mathrm{C}}$ values, and (G-I) $\Delta_{\mathrm{i}}$ values (y-values). Function

1151 performance was assessed separately for each taxon: $(A, D, G)$ arachnids $(n=10$ species for each

1152 function), $(\mathrm{B}, \mathrm{E}, \mathrm{H})$ crustaceans $(\mathrm{n}=28)$, and $(\mathrm{C}, \mathrm{F}, \mathrm{I})$ insects $(\mathrm{n}=41)$. Possible rankings ranged

1153 from 1 ("best" model) to 33 ("worst"). Values plotted are mean values per function and

1154 taxonomic group taken across all species datasets within that group $\pm 95 \%$ C.I.s. For names and

1155 details of development functions (\#1-33) the reader is referred to Table 1. Results of post-hoc

1156 comparisons among functions with Tukey's HSD test for each taxonomic group are presented in

1157 Table 2. 


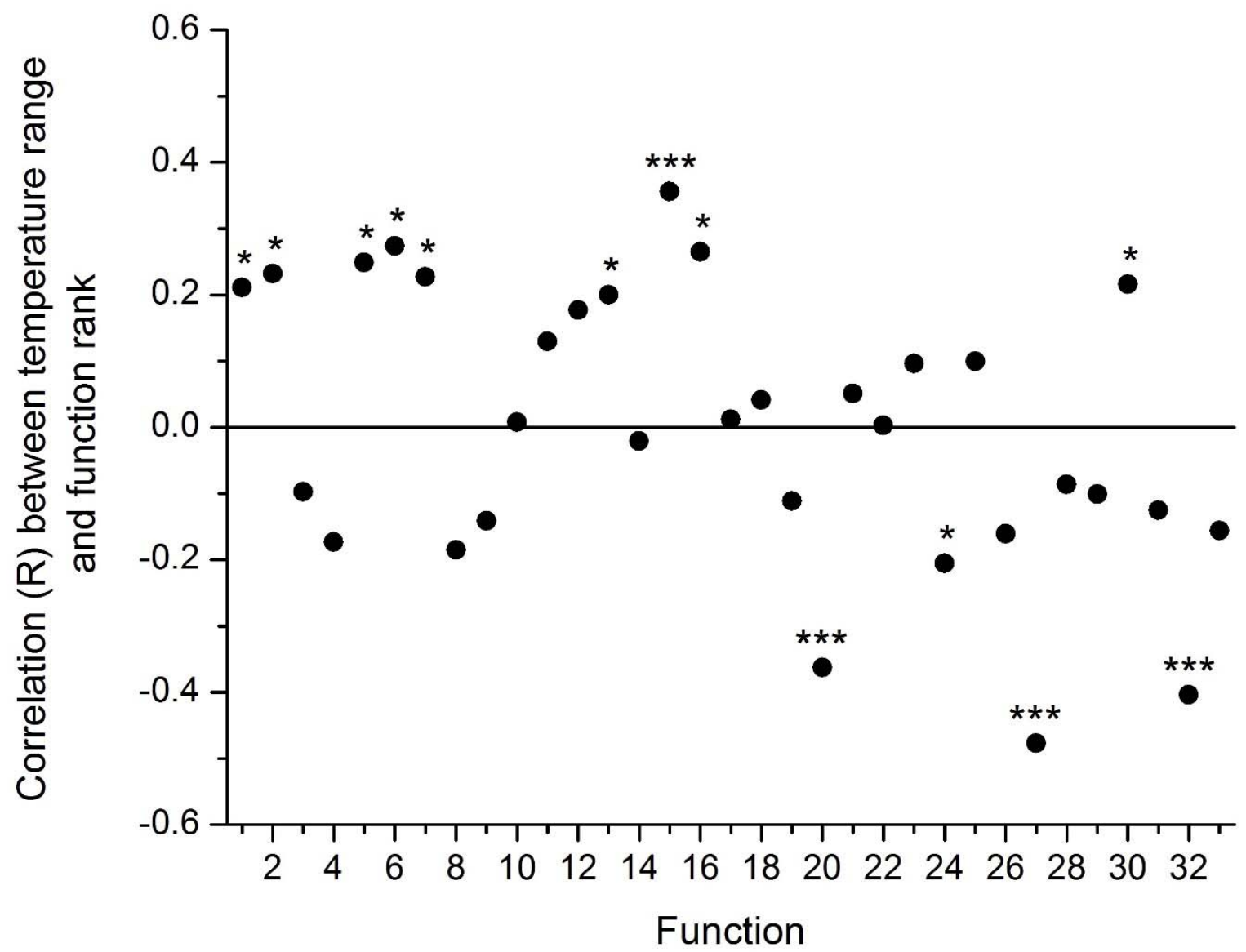

1160 Figure 7. Pearson's correlation coefficient values (R) calculated between the ranges of

1161 temperatures $\left({ }^{\circ} \mathrm{C}\right)$ tested in all original studies $(\mathrm{n}=99)$ and rank (out of 33) of development

1162 functions based on $\mathrm{AIC}_{\mathrm{C}}$ for each species dataset. Statistical significance of correlation

1163 coefficients is indicated by labels above each plotted point as follows: * $\mathrm{p} \leq 0.05$, * $\mathrm{p} \leq 0.01$,

$1164 * * * \mathrm{p}<0.001$; non-significant $(\mathrm{p}>0.05)$ results are not labelled. For names and details of

1165 development functions (\#1-33) the reader is referred to Table 1. 
Table 1. Names and forms of the 33 different development functions examined in this study. Functions are arranged and numbered first in order of their value of $k$ (number of parameters +1 , used in $\mathrm{AIC}_{\mathrm{C}}$ analyses), and then alphabetically by their common name. In all equations $\mathrm{D}$ is development time (in days), T is temperature $\left({ }^{\circ} \mathrm{C}\right), \mathrm{A}, \mathrm{B}, \mathrm{C}, \mathrm{F}, \mathrm{a}, \mathrm{b}, \mathrm{c}, \mathrm{d}, \mathrm{f}$, and $\mathrm{g}$ are fitted constants. Additional fitted constants in some equations with biological meaning and constrained values are as follows: $\mathrm{T}_{\min }=$ biological minimum temperature; $\mathrm{T}_{\max }=$ biological maximum temperature; $\mathrm{T}_{\mathrm{opt}}=$ temperature at which development rate is maximized; $\mathrm{K}=$ thermal constant, or the number of degree days required to complete development (Kontodimas et al., 2004); $\Delta \mathrm{T}=$ range of temperatures over development rate, and uppercase letters are used for functions fitted directly to time (D).

\begin{tabular}{|llll|}
\hline Function & $\boldsymbol{k}$ & Equation & Reference(s) \\
\hline (1) Arrhenius & 3 & $\mathrm{D}=1 /(\mathrm{a} * \mathrm{EXP}(\mathrm{b} /(\mathrm{T})))$ & Guerrero et al., 1994 \\
(2) Heip or power & 3 & $\mathrm{D}=\mathrm{A} * \mathrm{~T}^{\mathrm{B}}$ & Anger, 2001; Heip, 1974; Guerrero et al., 1994 \\
(3) Hyperbola & 3 & $\mathrm{D}=\mathrm{A} /\left(\mathrm{T}-\mathrm{T}_{\min }\right)$ & Hamasaki et al., 2009; Heip, 1974 \\
(4) Ikemoto and & 3 & $\mathrm{D} * \mathrm{~T}=\mathrm{K}+\mathrm{T}_{\min } * \mathrm{D}$ & Ikemoto and Takai, 2000; Papanikolaou et al., 2013 \\
Takai & & $\mathrm{D}=1 /\left(\left(\mathrm{T}-\mathrm{T}_{\min }\right) / \mathrm{K}\right)$ &
\end{tabular}




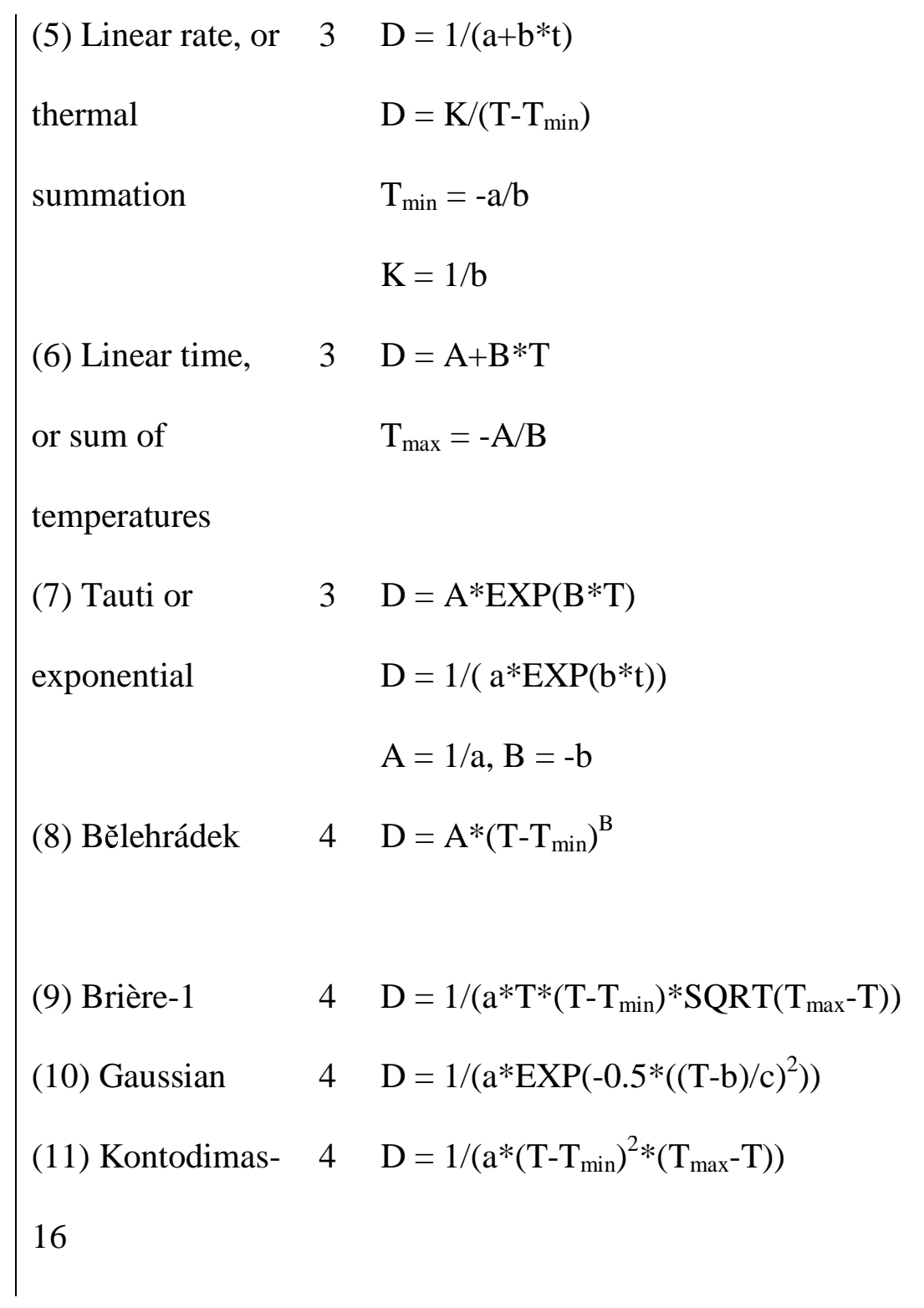

Campbell et al., 1974; Guerrero et al., 1994;

Kontodimas et al., 2004

Guerrero et al., 1994; Winberg, 1971

Anger, 2001; Guerrero et al., 1994; Tauti, 1925

Anger, 2001; Bělehrádek, 1935; Guerrero et al., 1994; Heip, 1974; McLaren, 1963

Brière et al., 1999; Shi and Ge, 2010

Shi and Ge, 2010; Taylor, 1981

Kontodimas et al., 2004 


\begin{tabular}{|c|c|c|c|}
\hline (12) Lactin-1 & 4 & $\mathrm{D}=1 /\left(\mathrm{EXP}\left(\mathrm{a}^{*} \mathrm{~T}\right)-\mathrm{EXP}\left(\mathrm{a}^{*} \mathrm{~T}_{\max } *\left(\left(\mathrm{~T}_{\max }-\mathrm{T}\right) / \Delta \mathrm{T}\right)\right)\right)$ & Lactin et al., 1995; Zhao et al., 2014 \\
\hline (13) Modified & 4 & $\mathrm{D}=1 /\left(\mathrm{a} * \mathrm{EXP}\left(\mathrm{b} /\left(\mathrm{T}-\mathrm{T}_{\min }\right)\right)\right)$ & Guerrero et al., 1994 \\
\hline \multicolumn{4}{|l|}{ Arrhenius } \\
\hline (14) Pradham- & 4 & $\mathrm{D}=1 /\left(\mathrm{a}^{*} \operatorname{EXP}\left(-0.5^{*}\left(\left(\mathrm{~T}-\mathrm{T}_{\mathrm{opt}}\right) / \mathrm{b}\right)^{2}\right)\right)$ & Golizadeh and Zalucki, 2012; Mobarakian et al., \\
\hline Taylor, or Taylor & & & 2014; Roy et al., 2002 \\
\hline (15) Quadratic & 4 & $\mathrm{D}=1 /\left(\mathrm{a} * \mathrm{~T}^{2}+\mathrm{b} * \mathrm{~T}+\mathrm{c}\right)$ & Mehrnejad, 2012 \\
\hline \multicolumn{4}{|l|}{ rate } \\
\hline (16) Quadratic & 4 & $\mathrm{D}=\mathrm{A}^{*} \mathrm{~T}^{2}+\mathrm{B} * \mathrm{~T}+\mathrm{C}$ & de Oliveira et al., 2009; Quinn et al., 2013 \\
\hline \multicolumn{4}{|l|}{ time } \\
\hline (17) Sigmoid, & 4 & $\mathrm{D}=1 /\left(\mathrm{c} /\left(1+\mathrm{EXP}\left(\mathrm{a}-\mathrm{b}^{*} \mathrm{~T}\right)\right)\right)$ & Davidson, 1942; Kontodimas et al., 2004 \\
\hline \multicolumn{4}{|l|}{ logistic, or } \\
\hline \multicolumn{4}{|l|}{ Davidson } \\
\hline (18) $3^{\text {rd }}$ order & 5 & $\mathrm{D}=1 /\left(\mathrm{a}^{*} \mathrm{~T}^{3}+\mathrm{b}^{*} \mathrm{~T}^{2}+\mathrm{c}^{*} \mathrm{~T}+\mathrm{d}\right)$ & Harcourt and Yee, 1982; Kontodimas et al., 2004 \\
\hline \multicolumn{4}{|l|}{ polynomial rate, } \\
\hline \multicolumn{4}{|l|}{ or Harcourt } \\
\hline (19) $3^{\text {rd }}$ order & 5 & $\mathrm{D}=\mathrm{A}^{*} \mathrm{~T}^{3}+\mathrm{B} * \mathrm{~T}^{2}+\mathrm{C} * \mathrm{~T}+\mathrm{F}$ & Bayoh and Lindsay, 2003; Harcourt and Yee, 1982 \\
\hline
\end{tabular}




\begin{tabular}{|c|c|c|c|}
\hline (20) Brière-2 & 5 & $\mathrm{D}=1 /\left(\mathrm{a}^{*} \mathrm{~T} *\left(\mathrm{~T}-\mathrm{T}_{\min }\right) *\left(\mathrm{~T}_{\max }-\mathrm{T}\right)^{(1 / \mathrm{b})}\right)$ & Brière et al., 1999; Shi and Ge, 2010 \\
\hline (21) Holling Type & 5 & $\mathrm{D}=1 /\left(\mathrm{a}^{*}\left(\left(\mathrm{~T}^{2} /\left(\mathrm{T}^{\wedge}{ }^{2}+\mathrm{b}^{2}\right)\right) * \operatorname{EXP}\left(\left(\mathrm{T}_{\max }-\mathrm{T}\right) / \Delta \mathrm{T}\right)\right)\right)$ & Hilbert and Logan, 1983; Holling, 1965; \\
\hline III, or Hilbert and & & & Kontodimas et al., 2004 \\
\hline \multicolumn{4}{|l|}{ Logan } \\
\hline \multirow[t]{2}{*}{ (22) Janisch } & 5 & $\mathrm{D}=\left(\mathrm{D}_{\min } / 2\right) *\left(\mathrm{EXP}\left(\mathrm{K}^{*}\left(\mathrm{~T}-\mathrm{T}_{\max }\right)\right)+\operatorname{EXP}\left(-\mathrm{A}^{*}\left(\mathrm{~T}-\mathrm{T}_{\max }\right)\right)\right)$ & Analytis, 1981; Janisch, 1932; Kontodimas et al., \\
\hline & & & 2004 \\
\hline (23) Lactin-2 & 5 & $\mathrm{D}=1 /\left(\mathrm{EXP}\left(\mathrm{a}^{*} \mathrm{~T}\right)-\mathrm{EXP}\left(\mathrm{a}^{*} \mathrm{~T}_{\max } *\left(\left(\mathrm{~T}_{\max }-\mathrm{T}\right) / \Delta \mathrm{T}\right)\right)+\mathrm{b}\right)$ & Kontodimas et al., 2004; Lactin et al., 1995 \\
\hline (24) Lamb, or & 5 & $\mathrm{D}=1 /\left(\mathrm{a}^{*} \operatorname{EXP}\left(-0.5^{*}\left(\left(\mathrm{~T}-\mathrm{T}_{\mathrm{opt}}\right) / \mathrm{T}_{\min }\right)^{2}\right)\right)$, if $\mathrm{T} \leq \mathrm{T}_{\mathrm{opt}}$ & Kontodimas et al., 2004; Lamb et al., 1984; Taylor, \\
\hline Taylor non- & & $\mathrm{D}=1 /\left(\mathrm{a}^{*} \operatorname{EXP}\left(-0.5^{*}\left(\left(\mathrm{~T}-\mathrm{T}_{\mathrm{opt}}\right) / \mathrm{T}_{\max }\right)^{2}\right)\right)$, if $\mathrm{T}>\mathrm{T}_{\mathrm{opt}}$ & 1981 \\
\hline \multicolumn{4}{|l|}{ symmetric Gauss } \\
\hline (25) Logan-6 (or & 5 & $\mathrm{D}=1 /\left(\mathrm{a} *\left(\mathrm{EXP}(\mathrm{b} * \mathrm{~T})-\mathrm{EXP}\left(\mathrm{b}^{*} \mathrm{~T}_{\max }-\left(\left(\mathrm{T}_{\max }-\mathrm{T}\right) / \Delta \mathrm{T}\right)\right)\right)\right)$ & Logan et al., 1976; Shi and Ge, 2010; Kontodimas \\
\hline Logan-1) & & & et al., 2004 \\
\hline (26) Modified & 5 & $\mathrm{D}=1 /\left(\mathrm{a}^{*} \operatorname{EXP}\left(-0.5^{*}(\mathrm{ABS}(\mathrm{T}-\mathrm{b}) / \mathrm{c})^{\mathrm{d}}\right)\right)$ & Angilletta Jr., 2006; Naish and Hartwell, 1988; Shi \\
\hline Gaussian & & & and Ge, 2010 \\
\hline (27) Ratkowsky & 5 & $\mathrm{D}=1 /\left(\left(\mathrm{a}^{*}\left(\mathrm{~T}-\mathrm{T}_{\min }\right) *\left(1-\mathrm{EXP}\left(\mathrm{b} *\left(\mathrm{~T}-\mathrm{T}_{\max }\right)\right)\right)\right)^{2}\right)$ & Ratkowsky et al., 1983; Shi and Ge, 2010 \\
\hline
\end{tabular}




\begin{tabular}{|c|c|c|c|}
\hline (28) Stinner & 5 & $\mathrm{D}=1 /\left(\mathrm{c} /\left(1+\mathrm{EXP}\left(\mathrm{a}+\mathrm{b}^{*} \mathrm{~T}\right)\right)\right)$, if $\mathrm{T} \leq \mathrm{T}_{\mathrm{opt}}$ & Kontodimas et al., 2004; Stinner et al., 1974 \\
\hline & & $\mathrm{D}=1 /\left(\mathrm{c} /\left(1+\mathrm{EXP}\left(\mathrm{a}+\mathrm{b}^{*}\left(2 * \mathrm{~T}_{\mathrm{opt}}-\mathrm{T}\right)\right)\right)\right)$, if $\mathrm{T}>\mathrm{T}_{\mathrm{opt}}$ & \\
\hline (29) Analytis & 6 & $\mathrm{D}=1 /\left(\mathrm{a}^{*}\left(\mathrm{~T}-\mathrm{T}_{\min }\right)^{\wedge} \mathrm{b} *\left(\mathrm{~T}_{\max }-\mathrm{T}\right)^{\mathrm{c}}\right)$ & Analytis 1977, 1981; Kontodimas et al., 2004 \\
\hline (30) Logan-10 (or & 6 & $\mathrm{D}=1 /\left(\mathrm{a}^{*}\left(\left(1 /\left(1+\mathrm{K}^{*} \mathrm{EXP}(-\mathrm{b} * \mathrm{~T})\right)\right)-\mathrm{EXP}\left(-\left(\mathrm{T}_{\max }-\mathrm{T}\right) /\right.\right.\right.$ & Kontodimas et al., 2004; Logan, 1988; Logan et al., \\
\hline Logan-2) & & $\Delta \mathrm{T})))$ & 1976; Shi and Ge, 2010 \\
\hline (31) Performance & 6 & $\mathrm{D}=1 /\left(\mathrm{m}^{*}\left(\mathrm{~T}-\mathrm{T}_{\min }\right) *\left(1-\mathrm{EXP}\left(\mathrm{K}^{*}\left(\mathrm{~T}-\mathrm{T}_{\max }\right)\right)\right)\right)$ & Huey and Stevenson, 1979; Shi and Ge, 2010 \\
\hline (32) Sharpe and & 7 & $\mathrm{D}=1 /\left(\mathrm{T}^{*}(\mathrm{EXP}(\mathrm{a}-(\mathrm{b} / \mathrm{T}))) /(1+\mathrm{EXP}(\mathrm{c}-(\mathrm{d} / \mathrm{T}))+\mathrm{EXP}(\mathrm{f}-\right.$ & Kontodimas et al., 2004; Schoolfield et al., 1981; \\
\hline DeMichele & & $(\mathrm{g} / \mathrm{T}))))$ & Sharpe and DeMichele, 1977 \\
\hline (33) Wang-Lan- & 8 & $\mathrm{D}=1 /\left(\left(\mathrm{K}^{*}\left(1-\mathrm{EXP}\left(-\mathrm{a}^{*}\left(\mathrm{~T}-\mathrm{T}_{\min }\right)\right)\right) *\left(1-\mathrm{EXP}\left(\mathrm{b}^{*}(\mathrm{~T}-\right.\right.\right.\right.$ & Shi and Ge, 2010; Wang et al., 1982 \\
\hline Ding (W-L-D) & & $\left.\left.\left.\left.\left.\mathrm{T}_{\max }\right)\right)\right)\right) /\left(1+\operatorname{EXP}\left(-\mathrm{c}^{*}(\mathrm{~T}-\mathrm{d})\right)\right)\right)$ & \\
\hline
\end{tabular}


1181 Table 2. Results of post-hoc comparisons of fit $\left(\mathrm{R}^{2}\right)$ and rank (based on comparisons of AIC

1182 values) among different development functions within each arthropod subphylum using Tukey’s

1183 HSD test. Functions with different letters in a particular column had significantly different values

1184 of $\mathrm{R}^{2}$ or rank; comparisons were not made among subphyla (i.e., among columns). Functions

1185 labelled with the letter ' $\mathrm{A}$ ' had the overall best performance (highest mean $\mathrm{R}^{2}$, rank closest to 1)

1186 while letters from $\mathrm{B}$ to $\mathrm{M}$ indicate progressively poorer function performance. Means of the $\mathrm{R}^{2}$

1187 and rank data compared in this table are plotted in Fig. 6. Post-hoc comparisons were not made

1188 of $\Delta_{\mathrm{i}}$ values because these did not differ significantly overall among functions. For names and

1189 details of development functions (\#1-33) the reader is referred to Table 1.

\begin{tabular}{|lllllll|}
\hline Function & & \multicolumn{2}{c}{$\mathbf{R}^{2}$} & & & \multicolumn{2}{c|}{ Rank } \\
& Arachnida & Crustacea & Insecta & Arachnida & Crustacea & Insecta \\
\hline 1 & $\mathrm{AB}$ & $\mathrm{ABCD}$ & $\mathrm{ABCD}$ & $\mathrm{BCDEF}$ & $\mathrm{CDEFGH}$ & EFGHIJ \\
3 & $\mathrm{~A}$ & $\mathrm{AB}$ & $\mathrm{AB}$ & $\mathrm{ABC}$ & $\mathrm{A}$ & $\mathrm{ABCD}$ \\
4 & $\mathrm{~A}$ & $\mathrm{AB}$ & $\mathrm{AB}$ & $\mathrm{A}$ & $\mathrm{A}$ & $\mathrm{AB}$ \\
5 & $\mathrm{AB}$ & $\mathrm{ABCD}$ & $\mathrm{ABCD}$ & $\mathrm{BCDEF}$ & $\mathrm{CDEFGH}$ & FGHIJLL \\
6 & $\mathrm{AB}$ & $\mathrm{ABC}$ & $\mathrm{ABCD}$ & $\mathrm{ABCDEF}$ & $\mathrm{CDEFG}$ & FGHIKL \\
7 & $\mathrm{~B}$ & $\mathrm{ABC}$ & $\mathrm{ABCD}$ & $\mathrm{DEF}$ & $\mathrm{DEFGH}$ & LM \\
8 & $\mathrm{AB}$ & $\mathrm{ABC}$ & $\mathrm{ABC}$ & $\mathrm{ABCDE}$ & $\mathrm{ABC}$ & $\mathrm{DEFGH}$ \\
9 & $\mathrm{~A}$ & $\mathrm{AB}$ & $\mathrm{A}$ & $\mathrm{A}$ & $\mathrm{A}$ & $\mathrm{A}$ \\
10 & $\mathrm{~A}$ & $\mathrm{D}$ & $\mathrm{ABCD}$ & $\mathrm{ABCDEF}$ & $\mathrm{EFGHI}$ & $\mathrm{CDEF}$ \\
11 & $\mathrm{AB}$ & $\mathrm{ABC}$ & $\mathrm{ABCD}$ & $\mathrm{ABCD}$ & $\mathrm{ABCD}$ & $\mathrm{BCDE}$ \\
\hline & $\mathrm{A}$ & $\mathrm{ABCD}$ & $\mathrm{ABCD}$ & $\mathrm{BCDEF}$ & $\mathrm{CDEFGH}$ & $\mathrm{DEFGHI}$ \\
\hline
\end{tabular}




\begin{tabular}{|c|c|c|c|c|c|c|}
\hline 12 & $\mathrm{AB}$ & ABCD & $\mathrm{ABCD}$ & ABCDEF & DEFGH & GHIJKLM \\
\hline 13 & $\mathrm{AB}$ & $\mathrm{ABC}$ & $\mathrm{ABCD}$ & $\mathrm{CDEF}$ & CDEFGH & EFGHIJ \\
\hline 14 & A & $\mathrm{ABC}$ & $\mathrm{ABCD}$ & $\mathrm{ABCD}$ & $\mathrm{ABCD}$ & $\mathrm{BCDE}$ \\
\hline 15 & $\mathrm{AB}$ & $\mathrm{ABC}$ & $\mathrm{ABCD}$ & $\mathrm{CDEF}$ & $\mathrm{ABCDE}$ & EFGHIJKL \\
\hline 16 & A & A & $\mathrm{AB}$ & $\mathrm{AB}$ & $\mathrm{AB}$ & $\mathrm{ABC}$ \\
\hline 17 & A & $\mathrm{ABC}$ & $\mathrm{ABCD}$ & $\mathrm{ABCDE}$ & $\mathrm{ABCD}$ & BCDE \\
\hline 18 & A & $\mathrm{ABC}$ & $\mathrm{ABCD}$ & $\mathrm{ABCDE}$ & BCDEF & EFGHIJ \\
\hline 19 & A & $\mathrm{ABC}$ & $\mathrm{ABCD}$ & $\mathrm{ABC}$ & $\mathrm{ABCD}$ & BCDE \\
\hline 20 & $\mathrm{AB}$ & $\mathrm{CD}$ & $\mathrm{ABCD}$ & $\mathrm{ABCD}$ & EFGHI & $\mathrm{BCDE}$ \\
\hline 21 & A & $\mathrm{ABCD}$ & $\mathrm{ABCD}$ & $\mathrm{EF}$ & $\mathrm{HI}$ & JKLM \\
\hline 22 & $\mathrm{AB}$ & $\mathrm{ABC}$ & $\mathrm{ABC}$ & $\mathrm{ABCDEF}$ & CDEFGH & EFGHIJKL \\
\hline 23 & $\mathrm{AB}$ & $\mathrm{ABC}$ & $\mathrm{ABCD}$ & BCDEF & EFGHI & GHIJKLM \\
\hline 24 & $\mathrm{AB}$ & $\mathrm{ABCD}$ & $\mathrm{ABCD}$ & $\mathrm{ABCDEF}$ & FGHI & EFGHIJKL \\
\hline 25 & $\mathrm{AB}$ & $\mathrm{ABCD}$ & $\mathrm{CD}$ & BCDEF & EFGHI & KLM \\
\hline 26 & A & $\mathrm{AB}$ & $\mathrm{ABCD}$ & $\mathrm{ABC}$ & $\mathrm{ABCDE}$ & $\mathrm{BCDE}$ \\
\hline 27 & $\mathrm{AB}$ & $\mathrm{BCD}$ & $\mathrm{ABCD}$ & $\mathrm{ABCDE}$ & GHI & EFGHIJ \\
\hline 28 & A & $\mathrm{ABC}$ & $\mathrm{ABCD}$ & $\mathrm{ABCDEF}$ & CDEFGH & EFGHIJK \\
\hline 29 & $\mathrm{AB}$ & $\mathrm{ABC}$ & $\mathrm{ABC}$ & $\mathrm{ABCDEF}$ & CDEFGH & DEFG \\
\hline 30 & B & $\mathrm{ABC}$ & $\mathrm{BCD}$ & $\mathrm{F}$ & $\mathrm{HI}$ & $\mathrm{M}$ \\
\hline 31 & $\mathrm{AB}$ & $\mathrm{ABC}$ & $\mathrm{ABCD}$ & BCDEF & GHI & HIJKLM \\
\hline 32 & $\mathrm{AB}$ & $\mathrm{ABC}$ & $\mathrm{ABC}$ & $\mathrm{ABCDE}$ & EFGHI & DEFG \\
\hline 33 & $\mathrm{AB}$ & $\mathrm{ABCD}$ & $\mathrm{D}$ & $\mathrm{EF}$ & I & IJKLM \\
\hline
\end{tabular}


Table 3. Consequences of fitting development data with functions used or found to be best in original published studies rather than the best function for each of 79 reanalyzed species datasets,

1194 as determined in this study. Consequences were assessed by calculating differences between

1195 used and actual best functions in terms of (1) increased mean error (absolute, in days) between

1196 observed and predicted development times, (2) increased percent (\%) prediction error, (3)

1197 usually poorer fit $\left(\mathrm{R}^{2}\right)$, (4) poorer percent $(\%)$ fit $\left(\mathrm{R}^{2}\right)$, and (5) information loss $\left(\Delta_{\mathrm{i}}\right.$ of used

1198 models; $\Delta_{\mathrm{i}}=0$ is the best model). resulting. Mean values $\pm 95 \%$ confidence intervals (95\% C.I.)

1199 for each difference measure taken across all retested datasets are shown (with the range of values

1200 in parentheses), as well as the results of one-sample t-tests comparing these differences to zero;

1201 statistically-significant $\mathrm{p}$-values $(\mathrm{p} \leq 0.05)$ are presented in bold text.

1202

\begin{tabular}{|lll|}
\hline $\begin{array}{l}\text { Measure of difference } \\
\text { between used and actual }\end{array}$ & $\begin{array}{l}\text { Mean } \pm \text { 95 \% C.I. } \\
\text { (Minimum }- \text { Maximum) }\end{array}$ & $\begin{array}{l}\text { Significance of } \\
\text { difference from zero }\end{array}$ \\
\hline Mean error (days) & $4.042 \pm 3.696(-0.024-132.342)$ & $\mathrm{t}_{78}=2.144, \mathbf{p}=\mathbf{0 . 0 3 5}$ \\
Mean error $(\%)$ & $85.913 \pm 53.666(-1.690-1725.529)$ & $\mathrm{t}_{78}=3.138, \mathbf{p}=\mathbf{0 . 0 0 2}$ \\
$\mathrm{R}^{2}$ & $-0.091 \pm 0.039(-0.873-0.002)$ & $\mathrm{t}_{78}=-4.620, \mathbf{p}<\mathbf{0 . 0 0 1}$ \\
$\mathrm{R}^{2}(\%)$ & $-10.736 \pm 4.595(-100-0.172)$ & $\mathrm{t}_{78}=-4.579, \mathbf{p}<\mathbf{0 . 0 0 1}$ \\
$\Delta_{\mathrm{i}}$ of used function & $225.011 \pm 118.316(0-3958.691)$ & $\mathrm{t}_{78}=3.727, \mathbf{p}<\mathbf{0 . 0 0 1}$ \\
\hline
\end{tabular}

